\title{
ACELERAÇÃO, INCUBAÇÃO E ECOSSISTEMA EMPREENDEDOR: ANÁLISE JURÍDICA DAS STARTUPS
}

\section{ACCELERATION, INCUBATION AND ENTREPRENEURSHIP ECOSYSTEM: LEGAL ANALYSIS OF STARTUPS.}

\author{
Henrique Avelino Lana \\ Eduardo Goulart Pimenta ${ }^{2}$
}

Recebido em: 21/05/2020 Aceito em: 27/07/2021

henriqueavel@htomail.com

\begin{abstract}
Resumo: Sabe-se que as startups estão em alta e em voga, em um mercado e cenário de investimentos de grande porte, com novas soluções para o mercado e surgimento de novas atividades a todo momento. Isso desperta enormes questionamentos jurídicos. O problema levantando neste artigo é verificar quais seriam as características técnicas, jurídicas, para se configurar uma start up, bem como identificar o que é, tecnicamente, aceleração, incubação e ecossistema empreendedor. A metodologia a ser utilizada é de método dedutivo, mediante abordagem explicativa e descritiva, com análise de bibliografia, nacional e estrangeira, toda ela especializada no cerne do tema.
\end{abstract}

Palavras-chave: Startups. Inovação. Direito. Ecossistema empreendedor.

\begin{abstract}
It is known that startups are on the rise and in vogue, in a large investment marke and scenario, with new solutions for the market and the emergence of new activities at all times. This raises huge legal questions. The problem raised in this article is to verify what the technical and legal characteristics would be for setting up a start up, as well as identifying what is, technically, acceleration, incubation and entrepreneurial ecosystem. The methodology to be used is a deductive method, by means of an explanatory and descriptive approach, with analysis of bibliography, national and foreign, all specialized in the core of the theme.
\end{abstract}

Keywords: startups. Innovation. Right. Entrepreneurial ecosystem.

\section{INTRODUÇÃO}

Sabe-se que as startups estão em alta e em voga. Vivencia-se um cenário de incertezas, investimentos de grande porte, novas soluções para o mercado e surgimento de novas atividades a todo momento. As startups são focadas na solução de problemas em massa, tendo um papel relevante na sociedade. O espírito é jovem e fortemente vinculado à pesquisa, investigação e ousadia. São visionárias, em meio às transformações do mercado e avanço irrefreável da tecnologia. A origem do termo startup no contexto dos negócios é realmente incerta e alude a um artigo publicado na Revista Forbes nos idos 1976. Tal artigo cuidava do desenvolvimento do setor de processamento de dados, abordando as startups como empresas de rápido crescimento no campo da tecnologia. Mas a palavra startup já era utilizada por autores economistas desde o século 17, sendo adaptada após a chegada da "bolha da internet" (1996-2001). Inclusive, o novo milênio evidenciou a difusão das empresas "ponto com", que se apropriaram do termo para designar sua nova visão dos negócios. O Vale do Silício se consolidou com as gigantes Facebook, Apple e Google, tornando-se um berço de startups e maior polo difusor da economia criativa e inovadora. Fato é que apesar do

\footnotetext{
${ }^{1}$ Pontifícia Universidade Católica de Minas Gerais. Minas Gerais. Brasil.

2 Pontifícia Universidade Católica de Minas Gerais/Universidade Federal de Minas Gerais. Minas Gerais. Brasil.
} 
forte laço com a tecnologia, uma startup não precisa, imprescindivelmente, trabalhar com produtos ou serviços digitais.

Também, revela-se errado classificar qualquer empresa (atividade) recém fundada ou pequeno negócio como se fosse uma startup, afinal, o que define esse tipo de empreendimento é o potencial de crescimento rápido e vertiginoso. Ou seja, a essência da startup é sua capacidade de escalar o negócio e crescer rapidamente. Ao se traduzir a palavra startup para o português, chega-se a termos como "arranque", "inicialização", "partida” e "lançamento". Isso é justamente o que buscam: dar a partida em negócios inovadores, arrancando na frente com soluções criativas que atingem milhões de pessoas. Já na concepção de investidores, a startup é uma oportunidade de alto risco, todavia, com possibilidade de retornos promissores.

Assim, o problema levantando neste artigo é verificar quais seriam as características técnicas, jurídicas, para se configurar uma start up, bem como identificar o que é, tecnicamente, aceleração, incubação e ecossistema empreendedor. A metodologia a ser utilizada é de método dedutivo, mediante abordagem explicativa e descritiva, com análise de bibliografia, nacional e estrangeira, toda ela especializada no cerne do tema.

A metodologia a ser utilizada é de método dedutivo, mediante abordagem explicativa e descritiva, com análise de bibliografia, nacional e estrangeira, toda ela especializada no cerne do tema.

\section{CARACTERÍSTICAS FUNDAMENTAIS DE UMA STARTUP: UMA ANÁLISE SEMPRE NECESSÁRIA.}

O que faria de um negócio uma startup? Pois bem. Elas têm características próprias e merecem ser compreendidas. Muito se ouve atualmente sobre este novo modelo de atividade que tem mostrado muito sucesso e conseguido altos investimentos e de grande monta. Há domínio crescente do mercado, mediante propostas inovadoras, espírito jovem, e totalmente relacionadas às tendências da transformação digital. As startups são a grande aposta do mercado e formam verdadeiros ecossistemas no mundo todo. São de baixo capital inicial e rápido crescimento, com DNA jovem e um modelo de negócio promissor. Para ingressar no universo das startups, não basta ter uma grande ideia. É preciso trabalhar duro, conhecer o cliente a fundo e ter coragem para correr riscos em busca de sonhos ambiciosos.

As startups são diferentes, por exemplo, das pequenas empresas recém abertas, e isso advém da expectativa que elas geram. Se mostram atividades iniciantes, detentoras de abordagem jovem e adaptadas ao modelo digital, tão importante nos dias atuais. Muito embora sejam pequenas, proporcionam propostas inovadoras de serviços a serem prestados ou produtos a serem produzidos e fabricados. Almeja-se gerar impacto por meio de algo que se revele novo e possua enormes possibilidades de desenvolvimento. Decorrem de ideias com boas chances de êxito de serem líderes e grandes players dos seus mercados.

A startup está em fase embrionária e busca um modelo de negócio repetível, escalável e altamente lucrativo, priorizando a inovação em um ambiente de alto risco. Pela definição de Eric Ries, 
autor do best-seller The Lean Startup (Crown Publishing Group, 2011) "Uma startup é uma instituição humana desenhada para criar um novo produto ou serviço em condições de extrema incerteza."

O risco é inerente e decorre do caráter experimental do negócio, pois sua operação é totalmente diferente das empresas convencionais. Isso, pois, enquanto os empreendedores tradicionais desenham um modelo previsível antes de iniciar suas operações, os idealizadores de startups partem de uma solução inovadora e a desenvolvem conforme recebem o feedback do mercado. A resposta dos clientes e investidores é que determina o sucesso da startup, que começa apenas com uma hipótese e arrisca tudo para provar, validar e consolidar o seu valor. Obviamente, chama a atenção de investidores. Já que inclusive muitos empreendedores iniciam esses negócios exatamente para a busca de investimentos para as suas ideias. Ocorre que o aporte financeiro apenas acontece caso a proposta seja diferenciada, sem possuir, em regra, nenhum precedente antes visto no mercado e com altas chances de sucesso. Vejam-se as características de uma startups.

O potencial de atingir grandes mercados com uma estrutura enxuta é um dos principais traços das startups. Com um capital inicial muito baixo, a empresa pode chegar a alcançar milhões de consumidores.

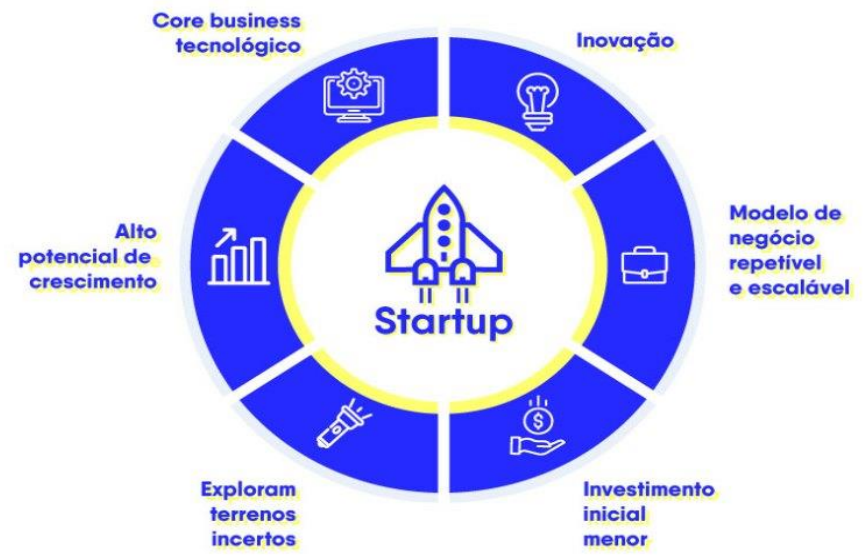

Startups estão fortemente relacionadas à tecnologia. Mesmo que o foco não seja uma solução voltada especificamente para a área, dificilmente algo terá resultado positivo se seus idealizadores não usarem essa ferramenta a favor. Se considerarmos ainda que um startup explora atividades inovadoras, esse conceito de aplicação de novas tecnologias fica ainda mais evidente e justificável. As principais características de uma startup são a inovação, a escalabilidade, a repetibilidade, a flexibilidade e a rapidez. Ou seja, conceitos muito semelhantes e próximos às novidades tecnológicas. Raramente algo é feito sem que haja influência da tecnologia, sobretudo quando se está falando de inovações. O próprio conceito do "novo" traz uma ideia futurista, como sendo uma forma de executar tarefas ou resolver questões que ainda não foram criadas. Inovação é 
a principal característica das startups. Inovar é o primeiro passo de uma empresa que deseja se lançar como startup.

Assim, o principal alicerce de uma startup é apresentar e desenvolver solução para problemas de uma maneira inovadora e nunca antes testada, mas que tem grandes chances de dar certo e se tornar um excelente negócio. Trazem serviços que sempre foram necessários, mas que nunca foram pensados antes. Igualmente, acontece com os produtos, pois servem como soluções certeiras referentes as inúmeras e diferentes demandas da sociedade.

São disruptivas. Isso pois as startups rompem e quebram padrões em relação a outras empresas do mesmo segmento, geralmente já consolidadas. Esta característica se denota por meio de formas de atendimento, isenção ou redução de taxas e até mesmo no modo como os serviços são prestados ou disponibilizados. Ou seja, o propósito é fugir do que o mercado oferece, destacando-se e auferindo a competitividade necessária. Ademais, são escaláveis, ou seja, detêm muita possibilidade de crescimento, vertiginoso, fazendo isso sem consequências ou limites nas suas operações.

Tal escalabilidade ocorre sobretudo por serem geralmente atreladas ao meio digital. Consequentemente, seus produtos e serviços podem ser entregues a um número cada vez maior de clientes, sem que enseje mais esforços, investimentos, gastos ou despesas. Um negócio escalável é aquele que pode crescer em um ritmo muito acelerado sem alterar o modelo proposto. Ou seja, a receita da empresa aumenta exponencialmente, mas os custos continuam praticamente os mesmos.

Uma startup é repetível, pois o mesmo produto ou serviço pode ser ofertado em larga escala, não possuindo nenhum tipo de limitação. Para tanto, deve ser pouco flexível ou customizável. Ser repetível é entregar os mesmos produtos e serviços de modo reprodutivo, sem a necessidade de customizar em excesso. A proposta é multiplicar e alcançar mais clientes e adaptações atrapalhariam essas metas.

Outra característica inerente: a incerteza. Isso pois uma startup não têm um direcionamento bem definido no que diz respeito ao sucesso e há alto risco de insucesso. Portanto, apesar de serem propostas sólidas e com grande chance de terem bons resultados, não possuem precedentes que a autorizem e ajudem a deter perspectivas claras e absolutas ao longo do tempo futuro. Insta mencionar que, como regra, atividades insertas no contexto do empreendedorismo digital possuem sua atuação pela rede mundial de computadores, dispensando-se locais físicos e também a necessidade de deslocamento para realizar atendimentos, consultas, reuniões, etc. Geralmente, são negócios praticamente $100 \%$ digitais.

E quais seriam as diferenças entre as startups e as pequenas empresas que também estão se lançando no mercado? De fato, muito embora seja uma dúvida plausível, existe uma distinção conceitual elementar e que faz as startups realmente diferentes qual seja: elas trazem inovação para um mercado específico. Por exemplo, se você constitui um hostel, será apenas um modelo de estabelecimento de hospedagens. Mas, de outro norte, se divulga um aplicativo que conecta e interage pessoas, que estejam em busca de onde ficar, com quem deseja alugar sua residência ou algum quarto, haverá então ideia inovador, já que além de trazer algo novo e nunca visto antes no mercado, haveria o fato de ser inteiramente digital. 
Diante da incerteza, a startup precisa ser muito flexível para acompanhar as mudanças e lidar com os períodos de altos e baixos. A rotina dos colaboradores é bastante dinâmica, pois a flexibilidade de horários e projetos é essencial para extrair o melhor de cada profissional. E, tendo em vista que as startups costumam ser pequenas, suas equipes precisam ser muito unidas e trabalhar em absoluta sinergia. São compostas por profissionais de alto nível e multidisciplinares, que buscam integrar todas as áreas da empresa e construir uma equipe sólida.

O termo startup é cada vez mais usado e está em destaque no mundo tecnológico e empreendedor, tendo ganhado maior notoriedade no final da década de 1990, com as chamadas empresas '.com' (OIOLI, 2019, p. 11).

De acordo com Erik Frederico Oioli (2019, p. 11), na legislação brasileira, não há uma definição clara do que seria startup, pois este termo sequer é utilizado no ordenamento jurídico brasileiro, senão de forma implícita, quando associadas à micro e pequenas empresas (artigo 61-A, da Lei Complementar 123/06), ou empresas voltadas para a área de pesquisa, desenvolvimento e inovação tecnológica (Lei 11.196/05).

Eric Ries (2012, p.26) define a startup como "uma instituição humana projetada para criar novos produtos e serviços sob condições de extrema incerteza". O Autor destrincha este conceito, ao argumento de que a parte mais importante nesta definição é o que ela omite, tendo em vista que o conceito de startup não diz respeito ao tamanho da empresa, a sua atividade ou o seu setor da economia.

Passei a perceber que a parte mais importante dessa definição é o que ela omite. Não diz nada a respeito do tamanho da empresa, da atividade ou do setor da economia. Qualquer pessoa que está criando um novo produto ou negócio sob condições de extrema incerteza é um empreendedor, quer saiba ou não, e quer trabalhe numa entidade governamental, uma empresa apoiada por capital de risco, uma organização sem fins lucrativos ou uma empresa com investidores financeiros decididamente voltada para o lucro (RIES, 2012, p. 26).

Deste conceito, são destacados pelo Autor, os termos instituição, produto, inovação e extrema incerteza como caracterizadores de uma startup.

Consideremos cada uma das partes. A palavra instituição conota burocracia, processo, até letargia. Como isso pode ser parte de uma startup? No entanto, as startups bem-sucedidas estão repletas de atividades associadas ao desenvolvimento de instituições: contratação de funcionários criativos, coordenação das atividades deles, e criação de uma cultura empresarial que gera resultados. Frequentemente, perdemos de vista o fato de que uma startup não consiste num produto, numa inovação tecnológica ou até mesmo numa ideia brilhante. Uma startup é maior do que a soma de suas partes; é uma iniciativa intensamente humana. $O$ fato de que o produto ou serviço da startup é uma nova inovação também é parte essencial da definição, e também uma parte delicada. Prefiro empregar a definição mais ampla de produto, aquela que abrange qualquer fonte de valor para as pessoas que se tornam clientes. Qualquer coisa que os clientes vivenciam da interação com uma empresa deve ser considerada parte do produto daquela empresa. Isso é verdade em relação a uma quitanda, um site de comércio eletrônico, um serviço de consultoria e uma 
entidade de serviço social sem fins lucrativos. Em todos os casos, a organização se dedica a revelar uma nova fonte de valor para os clientes e se preocupa com o impacto do seu produto sobre esses clientes.

Também é importante que a palavra inovação seja compreendida amplamente. As startups utilizam muitos tipos de inovação: descobertas científicas originais, um novo uso para uma tecnologia existente, criação de um novo modelo de negócios que libera um valor que estava oculto, ou a simples disponibilização do produto ou serviço num novo local ou para um conjunto de clientes anteriormente mal atendidos. Em todos esses casos, a inovação é o cerne do sucesso da empresa. Há mais uma parte importante dessa definição: o contexto no qual a inovação acontece. A maiorias das empresas - grandes e pequenas - estão excluídas desses contextos. As startups são projetadas para enfrentar situações de extrema incerteza. Abrir uma nova empresa, que seja um clone exato de um negócio existente, copiando modelo de negócios, precificação, cliente-alvo e produto, pode até ser um investimento econômico atraente, mas não é uma startup, pois seu sucesso depende somente da execução - tanto que esse sucesso pode ser modelado com grande exatidão. (Eis por que tantas pequenas empresas podem ser financiadas com simples empréstimos bancários; o nível de risco e incerteza são tão bem entendidos que um analista de crédito pode avaliar suas perspectivas futuras.)

A maioria das ferramentas da administração geral não são projetadas para florescer no solo adverso da extrema incerteza, no qual as startups vicejam. O futuro é imprevisível, os clientes testemunham um conjunto crescente de alternativas, e o ritmo da mudança está sempre aumentando. No entanto, a maioria das startups - tanto em garagens quanto em empresas - ainda é administrada por meio de prognósticos padrão, marcos de produtos e planos de negócios detalhados (RIES, 2012, p. 26-27).

Bruno Feigelson, Erik Fontenele Nybø e Victor Cabral Fonseca dão um conceito mais amplo sobre o que é uma startup. Para os autores, uma startup é "um grupo de pessoas à procura de um modelo de negócios, baseado em tecnologia, repetível e escalável, trabalhando em condições de extrema incerteza" (FEIGELSON; NYBØ; FONSECA, 2018, p. 31). Uma grande vantagem do modelo de negócio adotado pelas startups é a efetiva capacidade de o produto ser replicável e escalável em virtude do uso da tecnologia, em que ser replicável significa que "é possível entregar o produto ou o serviço em escala de maneira potencialmente ilimitada, sem a necessidade de adaptação ou customização para cliente", enquanto ser escalável significa que a startup "tem capacidade para crescer cada vez mais por meio da venda de um produto ou serviço que pode ser produzido ou distribuído em grandes quantidades, resultando em uma economia de escala, sem a necessária alteração do modelo de negócios ou ampliação significativa de seus custos" (FEIGELSON; NYBØ; FONSECA, 2018, p. 34-35).

Além das características acima, Bruno Feigelson, Erik Fontenele Nybø e Victor Cabral Fonseca (2018, p. 24-26) também trazem as seguintes características de uma startup. Seu produto ou serviço é operacionalizado por meio de um produto mínimo viável (MVP), que é o desenvolvimento do produto ou serviço de uma forma simples, apenas para que seja possível verificar se realmente existe demanda e para manter os custos iniciais baixos; o produto ou ideia explorado é escalável, isto é, ser facilmente expandido para outros mercados e em diferentes níveis de capilaridade e distribuição, de modo a alcançar uma economia de escala por meio de replicação de um mesmo produto para inúmeros clientes; encontra-se em estágio inicial, sendo notadamente carente de processos internos e organização, muitas vezes sem um modelo de negócio claro; possui perfil 
inovador, sendo esta uma das características mais importantes; possui significativo controle de gastos e custos, de modo a focar os investimentos no desenvolvimento de seu produto ou serviço principal; apresenta necessidade de capital de terceiros para operação inicial, razão pela qual é comum a busca por investidores externos para financiamento das operações; utiliza tecnologia a favor do seu modelo de negócio, para desenvolver negócios escaláveis e inovadores; atuam em um mercado de extrema incerteza, em razão do alto risco.

Fato é que apesar do forte laço com a tecnologia, uma startup não precisa, imprescindivelmente, trabalhar com produtos ou serviços digitais. As startups são a grande aposta do mercado e formam verdadeiros ecossistemas no mundo todo. São de baixo capital inicial e rápido crescimento, com DNA jovem e um modelo de negócio promissor. Para ingressar no universo das startups, não basta ter uma grande ideia. É preciso trabalhar duro, conhecer o cliente a fundo e ter coragem para correr riscos em busca de sonhos ambiciosos.

As startups se mostram atividades iniciantes, detentoras de abordagem jovem e adaptadas ao modelo digital, tão importante nos dias atuais. Muito embora sejam pequenas, proporcionam propostas inovadoras de serviços a serem prestados ou produtos a serem produzidos e fabricados. Almeja-se gerar impacto por meio de algo que se revele novo e possua enormes possibilidades de desenvolvimento. Decorrem de ideias com boas chances de êxito de serem líderes e grandes players dos seus mercados.

A startup está em fase embrionária e busca um modelo de negócio repetível, escalável e altamente lucrativo, priorizando a inovação em um ambiente de alto risco. O potencial de atingir grandes mercados com uma estrutura enxuta é um dos principais traços das startups. Com um capital inicial muito baixo, a empresa pode chegar a alcançar milhões de consumidores.

Startups estão fortemente relacionadas à tecnologia. Mesmo que o foco não seja uma solução voltada especificamente para a área, dificilmente algo terá resultado positivo se seus idealizadores não usarem essa ferramenta a favor. Se considerarmos ainda que uma startup é uma empresa que explora atividades inovadoras, esse conceito de aplicação de novas tecnologias fica ainda mais evidente e justificável.

As principais características de uma startup são a inovação, a escalabilidade, a repetibilidade, a flexibilidade e a rapidez. Ou seja, conceitos muito semelhantes e próximos às novidades tecnológicas.

Atualmente, raramente algo é feito sem que haja influência da tecnologia, sobretudo quando se está falando de inovações. Aliás, o próprio conceito do "novo" traz uma ideia futurista, como sendo uma forma de executar tarefas ou resolver questões que ainda não foram criadas. Saliente-se que a inovação é a principal característica das startups. Inovar é o primeiro passo de uma empresa que deseja se lançar como startup. O principal alicerce de uma startup é apresentar e desenvolver solução para problemas de uma maneira inovadora e nunca antes testada, mas que tem grandes chances de dar certo e se tornar um excelente negócio.

Assim, trazem serviços que sempre foram necessários, mas que nunca foram pensados antes. O mesmo ocorre com os produtos, pois servem como soluções certeiras referentes as inúmeras e diferentes demandas da sociedade. As startups rompem e quebram padrões em relação a 
outras empresas do mesmo segmento, geralmente já consolidadas. Esta característica se denota por meio de formas de atendimento, isenção ou redução de taxas e até mesmo no modo como os serviços são prestados ou disponibilizados. O intuito é fugir do que o mercado oferece, destacandose e auferindo a competitividade necessária.

Por serem escaláveis, detêm muita possibilidade de crescimento, vertiginoso, fazendo isso sem consequências ou limites nas suas operações. Isso ocorre sobretudo por serem geralmente atreladas ao meio digital. Seus produtos e serviços podem ser entregues a um número cada vez maior de clientes, sem que enseje mais esforços, investimentos, gastos ou despesas. Por ser escalável, pode crescer em um ritmo muito acelerado sem alterar o modelo proposto. Logo, a receita da empresa aumenta exponencialmente, mas os custos continuam praticamente os mesmos. Por ser repetível, o mesmo produto ou serviço pode ser ofertado em larga escala, não possuindo nenhum tipo de limitação. Para tanto, deve ser pouco flexível ou customizável. O intuito é entregar os mesmos produtos e serviços de modo reprodutivo, sem a necessidade de customizar em excesso, multiplicando e alcançando mais clientes.

Por haver incerteza, não tem um direcionamento bem definido no que diz respeito ao sucesso e há alto risco de insucesso. Muito embora sejam propostas sólidas e com grande chance de terem bons resultados, não possuem precedentes que a autorizem e ajudem a deter perspectivas claras e absolutas ao longo do tempo futuro.

Como regra, atividades insertas no contexto do empreendedorismo digital possuem sua atuação pela rede mundial de computadores, dispensando-se locais físicos e também a necessidade de deslocamento para realizar atendimentos, consultas, reuniões, etc. Geralmente, são negócios praticamente $100 \%$ digitais.

As startups pairam em torno de produtos e serviços realmente inovadores. Logo, ao se ter boas reflexões e ser atento a serviços que podem ter êxito e sucesso, mais cedo ou mais tarde, ideias totalmente incríveis tendem a surgir. No mesmo sentido, qualquer startup decorre a partir de uma fase de protótipo, pela qual o modelo de negócio será testado perante o seu público-alvo, em uma amostragem reduzida e pequena. É importante começar por uma versão básica, compreender e observar os resultados que ela obtém, avaliando-se a reação do público. Depois dos testes, também será possível e relevante focar nas adaptações para se chegar ao modelo final. Para criar uma, devese ter bons parceiros, pois começar sozinho é sempre muito difícil. Precisam de diferentes competências para serem exercidas por pessoas de confiança dentro do seu networking, que possuam habilidades complementares à sua.

Passemos a alguns exemplos cotidianos. O Uber, que pesar de se considerar apenas uma empresa de $\mathrm{TI}$, se tornou uma das gigantes do transporte, em que conecta motoristas particulares junto a passageiros que desejam corridas por toda a cidade, que esteja em qualquer lugar do mundo. Quando adveio, causou competitividade aos táxis, proporcionando ao público uma opção a mais, acabando-se com um notório monopólio de décadas existente. 
Outro exemplo: Spotify. Afinal, em um contexto no qual os sites de download ilegal de músicas estavam sendo proibidos, o Spotify chegou com uma solução certeira: uma plataforma de streaming, em que seus usuários pagam um valor mensal e têm acesso a uma seleção enorme de canções. Isso o consolidou e, mesmo ganhando vários concorrentes, de fato, ainda é a maior empresa do seu segmento.

Outra: a Sympla. Esta lançou uma plataforma voltada a quem almeja fazer algum evento. Via sua solução, qualquer um pode cuidar de várias etapas de organização, já que permite vender ingressos, gerir as confirmações e inclusive trabalhar em todo o controle, valendo-se do aplicativo e de seu dashboard ${ }^{3}$ para a internet.

Também pode-se mencionar a Airbnb, pois esta possibilitou que pessoas de todo o mundo disponibilizassem suas residências com a finalidade de receber viajantes. Assim, se um indivíduo tem um imóvel desocupado, ou até mesmo, apenas um quarto vazio, tornou-se possível abrigar alguém por determinado tempo, angariando e obtendo dinheiro com isso. Também atua de forma totalmente digital, por meio do seu aplicativo ou pelo site. Pelo Airbnb, o lucro surge vem por meio das taxas cobradas em cada avença de aluguel.

Uma startup pode ser iniciada por qualquer pessoa, mas é importante que os principais passos para começar sejam obedecidos, pois todos são indispensáveis, desde a ideia até a busca por investimentos. É salutar possuir uma ideia inovadora. As startups pairam em torno de produtos e serviços realmente inovadores. Logo, ao se ter boas reflexões e ser atento a serviços que podem ter êxito e sucesso, mais cedo ou mais tarde, ideias totalmente incríveis tendem a surgir. Decorre a partir de uma fase de protótipo, pela qual o modelo de negócio será testado perante o seu público-alvo, em uma amostragem reduzida e pequena.

\footnotetext{
${ }^{3}$ Tipo de interface gráfica do usuário que geralmente fornece visualizações rápidas dos principais indicadores de desempenho relevantes para um objetivo ou processo de negócios específico. Permite "relatório de progresso" ou "relatório".
} 
É importante começar por uma versão básica, compreender e observar os resultados que ela obtém, avaliando-se a reação do público. Depois dos testes, também será possível e relevante focar nas adaptações para se chegar ao modelo final. Para criar uma, deve-se ter bons parceiros, pois começar sozinho é sempre muito difícil. Precisam de diferentes competências para serem exercidas por pessoas de confiança dentro do seu networking, que possuam habilidades complementares à sua. Este fator irá assegurar adequada eficiência futuramente, quando lançada e divulgada no mercado. Insta dizer que a captação de investimentos é parte fundamental do trabalho de uma startup. Isso pois grandes empresários, famosos fundos de investimentos e/ou outras companhias, como regra, querem e desejam investir.

Há diversas alternativas disponíveis de investimentos. Dentre as principais alternativas há o Bootstrapping (financiamento com recursos próprios dos sócios), Money Love (que são principalmente amigos e familiares), Investidores Anjo (focado para startups pequenas e que precisam não apenas de recursos, mas de conexões e conselhos), crowdfunding (onde os recursos têm origem em pessoas físicas e são captados de forma coletiva) e o Venture Capital (geralmente investimentos maiores, em empresas um pouco mais maduras, com uma participação mais ativa do investidor). Há também a possibilidade de buscar financiamento de aceleradoras e incubadoras.

Formas de

Apoio e financiamento

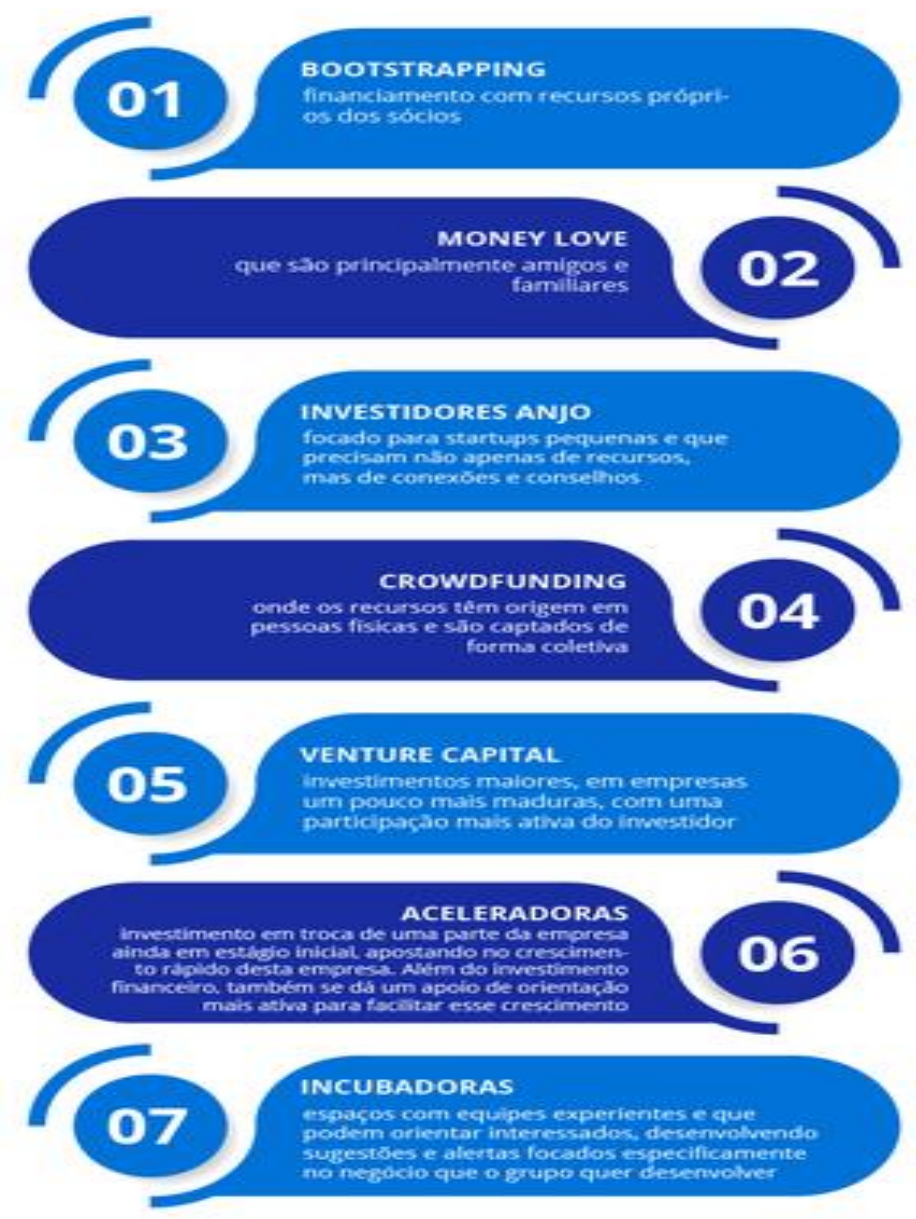

Revista do Direito [ISSN 1982-9957]. Santa Cruz do Sul, n. 63, p. 131-162, jan. 2021. https://online.unisc.br/seer/index.php/direito/index 
Segundo dados da Associação Brasileira de Startups, (ABStartups), o Brasil possui mais de 13 mil startups distribuídas em 588 cidades, sendo 60\% na região Sudeste. Essas são conduzidas por 10,1 mil empreendedores organizados em 74 "comunidades". Conforme o levantamento Radiografia do Ecossistema Brasileiro de Startups, elaborado pela ABStartups em parceria com a consultoria Accenture, $42 \%$ têm até dois anos e $69 \%$ não ultrapassam $R \$ 50$ mil de faturamento. Deste universo, $63 \%$ têm até cinco pessoas e $49 \%$ são compostas pelos sócios somente. Do total, $77 \%$ atuam voltadas ao mercado corporativo.

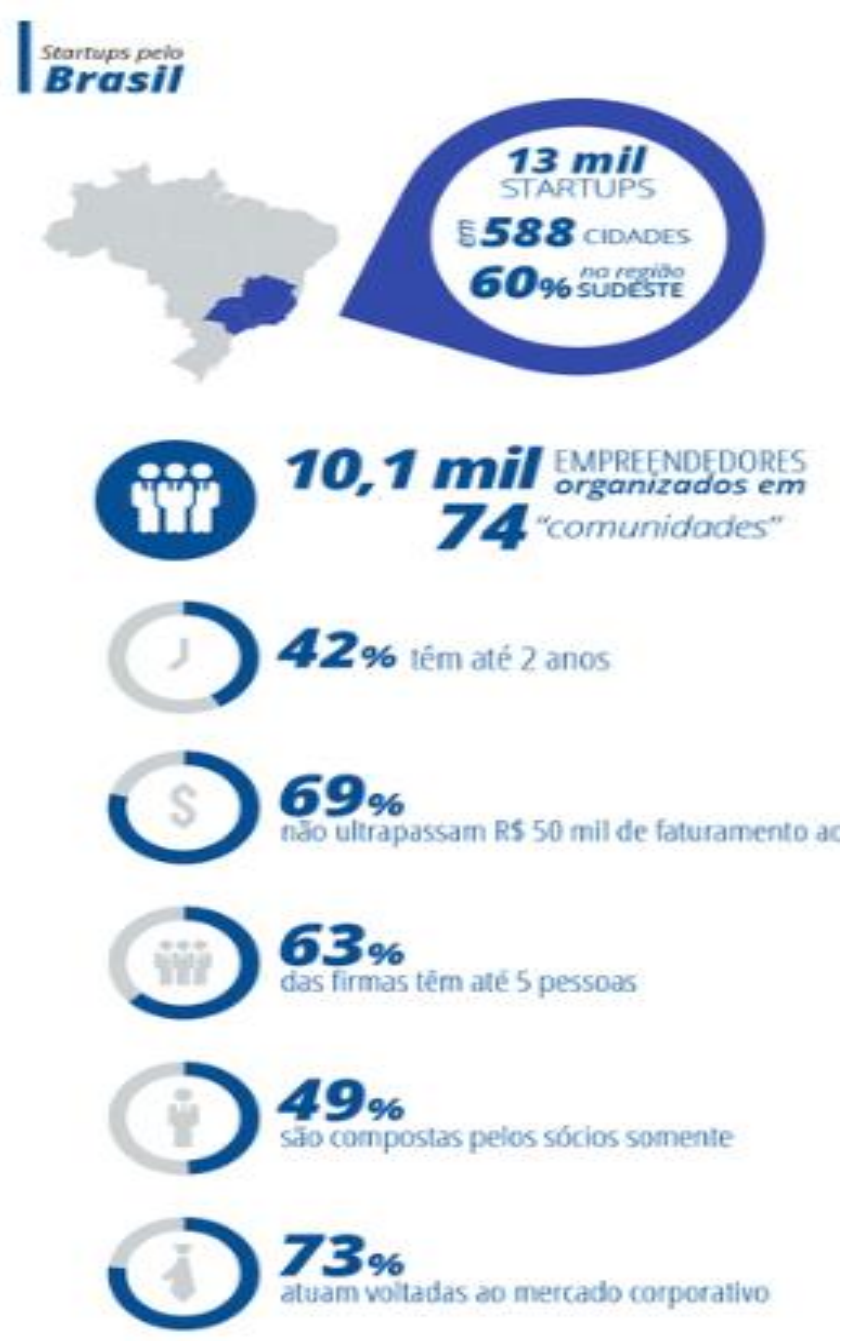

Fonte : Associagbo Erasileira de Srartups, ABSteartups?. 
Um relatório da consultoria McKinsey sobre a economia digital no Brasil, divulgado em 2019, apontou um índice alto de empreendimentos que não conseguem se manter no mercado: $66 \%$. De acordo com tal levantamento, as maiores dificuldades relatadas por startups ouvidas foram o engajamento dos consumidores (23\%), marketing (13\%), precificação e obtenção de receitas (11\%), obtenção de financiamento (11\%) e construção da tecnologia (9\%).

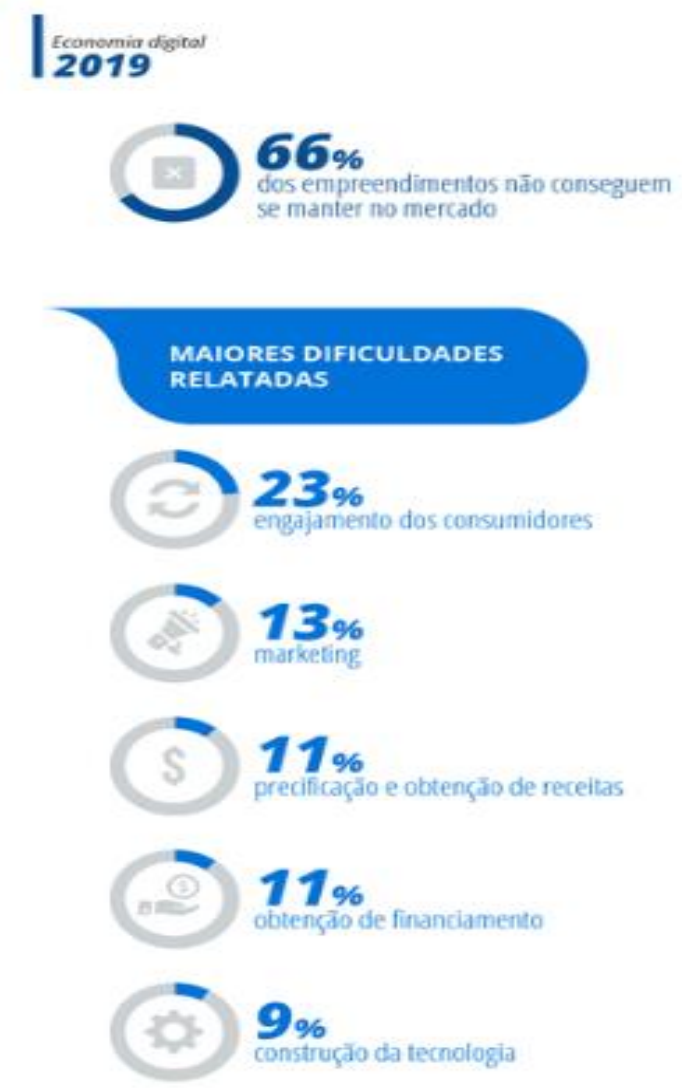

Economia digital 2019 - Arte EBC

Nota-se que o ponto de partida de toda startup é criar uma solução inovadora para um problema que ainda não foi devidamente solucionado pelo mercado. Os autores Alexander Osterwalder e Yves Pigneur escreveram o livro Business Model Generation (OSF, 2009) para auxiliar na definição do modelo de negócio das startups, que recebe o nome de Business Model Canvas e auxilia empreendedores a transformarem suas ideias em ações, atualmente muito utilizado em startups. Perpassa pela segmentação de clientes, proposta de valor, escolha de canais, estratégias de relacionamento, fontes de receita, atividades-chave e parceriaschave.

O banco de dados Startup Base da Associação Brasileira de Startups detém quase 7 mil empresas cadastradas e reúne negócios categorizados em Licenciamento, Marketplace, API, Ecommerce, Hardware, SaaS e vários outros segmentos. Mencione-se que outra forma de classificar 
as startups seria de acordo com seu objetivo, tal como descrito no artigo do professor Steve Blank para o The Wall Street Journal:

- Startups à venda: projetadas para atrair compradores após atingir resultados.

- Sociais: querem fazer a diferença na sociedade e construir um mundo melhor.

- Corporativas: são empresas tradicionais que se apropriam do modelo startup.

- Lifestyle: criadas por quem deseja trabalhar com o que ama de verdade.

- PME: possuem objetivos menos ambiciosos, como os pequenos negócios

- Escaláveis: já nascem com o propósito de se tornarem gigantes

Outro modelo reconhecido é o de "startup enxuta", proposto por Eric Ries, que se baseia em uma metodologia de rápida passagem pelos ciclos "construir, medir e aprender". O modelo da startup enxuta ou lean startup transforma ideias nos chamados Produtos Mínimos Viáveis (MVP). Estes representam o menor produto capaz de percorrer o ciclo de feedback com o menor esforço e de forma mais rápida. Por ele, cria-se uma cultura de experimentação junto ao cliente, escutando suas necessidades para oferecer o melhor produto possível sem desperdiçar nenhum recurso.

Pelo modelo da startup enxuta, o funcionamento da startup vai por um ciclo de construção, mensuração de resultados e aprendizagem. Incialmente a ideia é transformada em produto. Após a reação dos clientes é medida e, posteriormente, só então, a empresa aprende como direcionar seus esforços para o sucesso. O modelo organizacional das startups se diferencia das empresas tradicionais, pois seu crescimento se baseia na aprendizagem e experimentação contínua. A sua estrutura também é diferente, com equipes enxutas em espaços descontraídos e inspiradores, já que o espírito inovador e ágil das startups enseja um modelo muito mais flexível, dinâmico e criativo. Com esses diferenciais, as startups e as empresas de tecnologia vêm revolucionando a forma de se empreender no Brasil e no mundo.

Enquanto grandes empresas tradicionais tentam sobreviver à crise econômica que permeia o Brasil, as startups ganham os mercados e crescem a ritmos elevados. Deste modo, percebe-se que a capacidade de captar clientes e de ampliar o faturamento, mesmo diante de um cenário e contexto econômico instável, decorre principalmente da forma inovadora de sua formatação e atuação. As startups possuem pretensos modelos de negócios arrojados e inovadores, que identificam e buscam sanar a "dor" existente no mercado, mediante as novas formas de recepção de investimentos, valendo-se de contratos específicos, incluindo uso de tecnologias em seu favor.

Isso, dentre outros, são alguns dos fatores que tornam tais atividades singulares, significando também parte do segredo do sucesso desse novo padrão de se fazer negócios, cada vez mais presente e visto em nosso dia a dia.

\section{AS INCUBADORAS E ACELERADORAS: IMPRESCINDÍVEL IMPORTÂNCIA}

Verifica-se que as incubadoras iniciaram no Brasil nos anos 80. Apresentam uma grande estrutura que possui a finalidade de criar, desenvolver, recepcionar e abrigar empresas principalmente na área da ciência e tecnologia. As incubadoras podem acompanhar a partir do 
planejamento até as reais atividades. Empresas já existentes podem fazer parte das Incubadoras e, para tanto, basta intentar desenvolver o projeto buscando melhoria no serviço e produto.

Essencialmente, não buscam apenas o lucro. Geralmente, se encontram em centros de pesquisas, parques tecnológicos e universidades. Isto, por si, já proporciona mais credibilidade a sua empresa e disponibiliza um espaço de aprendizagem para alunos daquela determinada área, acarretando um benefício recíproco e mútuo, já que a empresa ganha mão de obra a mais para desenvolver seu projeto e esse aluno cresce no mercado de trabalho, cumprindo até mesmo sua função social.

A maioria das empresas ficam em média 3 anos nas incubadoras, mas não é uma regra. $\mathrm{O}$ sucesso vai depender exclusivamente de quanto os seus negócios foram desenvolvidos, podendo ser de curto ou longo prazo. Em contrapartida, é preciso pagar uma taxa mínima para que cubra algumas despesas. Elas têm a vantagem de desenvolver tecnologia e diversificar o meio econômico da região. Permite treinamentos e trocas de experiências.

Existem Incubadoras abertas e fechadas. A única diferença é que na aberta o espaço não é pré-definido e as empresas ficam dispersas. Assim, vê-se que as incubadoras de empresas são instituições que auxiliam micro e pequenas empresas nascentes ou que estejam em operação, que tenham como principal característica a oferta de produtos e serviços no mercado com significativo grau de inovação. As incubadoras então oferecem auxílio e suporte técnico, gerencial e formação complementar ao empreendedor. Ademais, facilitam o processo de inovação e acesso a novas tecnologias nos pequenos negócios. A incubadora é um processo mais antigo, havendo inúmeras delas instaladas nas mais diversas regiões brasileiras, normalmente sendo vinculadas a uma universidade, que aluga o espaço para novos empreendimentos a custos menores, permitindo que possam dar início aos seus negócios. Sendo de origem acadêmica, na maior parte das vezes, o networking entre empreendedores se torna mais fácil. $\mathrm{Na}$ incubadora, o empreendimento é acompanhado desde a fase de planejamento.

Por meio de instituições de ensino e pesquisa, órgãos governamentais e iniciativas privadas, permite-se nas incubadoras a instalação de escritórios ou laboratórios, auditórios, área para demonstração dos produtos, secretaria, bibliotecas sala de reunião, além inúmeros outros benefícios. As incubadoras proporcionam então, também, estrutura construído e adaptado para alojar temporariamente os empreendedores dando acesso a serviços que as empresas incubadas dificilmente encontrariam, caso estivessem sem orientação adequada no mercado e sozinhas. As incubadoras auxiliam, portanto, quanto a gestão empresarial; gestão tecnológica; comercialização de produtos e serviços; contabilidade; marketing; assistência jurídica; captação de recursos; contratos com financiadores; engenharia de produção e propriedade intelectual. Para participar é preciso ter um projeto para melhoria ou desenvolvimento de novos produtos e serviços.

Assim, pode ser qualquer pessoa que tenha um projeto inovador e deseja abrir sua própria atividade. As já existentes também podem participar do programa e receber o apoio da incubadora. As incubadoras auxiliam também o pesquisador e/ou profissional que tem uma tecnologia e almeja constituir sua própria empresa com um produto e processo inovador. A Aceleradora possui o mesmo 
intuito que a incubadora, entretanto, existem diferenças a serem destacadas para que não ocorra uma escolha indesejada.

De fato, as Incubadoras são mais amplas no Brasil. Mas é necessário reforçar que apesar do número ser maior que o de aceleradoras, isso que não quer dizer que uma detém maior credibilidade que a outra. Pelo contrário, trata-se de propostas diferentes, destinadas ao tempo necessário que o empreendedor deseja alcançar o seu sucesso. É certo, porém que as Aceleradoras têm crescido cada vez mais no mercado tecnológico e de aplicações de investimentos. Pelas Aceleradoras, os lucros são mantidos por investidores até a empresa atingir o seu equilíbrio, fase conhecida como "break even".

Assim, pode-se dizer que as Aceleradoras investem e oferecem serviços, bem como financiam o projeto desde o início e, ao final, transforma-se em sócia até o desenvolvimento completo, consolidação, aceitação e validação, momento em que provavelmente será vendida a ideia para outros investidores. Aceleradoras priorizam startups escaláveis, ou seja, de forma uniforme, com alta demanda.

Em Belo Horizonte há um ótimo exemplo e referência de Aceleradora é o SEED - Startups and Entrepreneurship Ecosystem Development. É um programa que busca inovação e proporciona experiências aos acelerados. O SEED é a única aceleradora com recursos públicos do Brasil e potencializa a interação, as redes e a transferência de conhecimento e habilidades entre empreendedores apoiados e o ecossistema local.

Coordenado pela Secretaria de Desenvolvimento Econômico, Ciência, Tecnologia e Ensino Superior - SEDECTES, o SEED é parte do Minas Digital, uma série de iniciativas governamentais, parcerias e rede de networking que busca impulsionar o desenvolvimento de negócios inovadores e fortalecer a cultura empreendedora no Estado. São 40 startups selecionadas por rodada, que indicam de dois a três empreendedores para serem ativos durante o período e recebem capital semente de até $\mathrm{R} \$ 80$ mil. Nele, os editais são abertos e, se for selecionada, disponibilizam-se toda estrutura física, contatos, palestras, investimento financeiro mensal para os participantes do projeto além de valores para aquisição de serviços e materiais necessários. O SEED - Startups and Entrepreneurship Ecosystem Development é um programa de aceleração de startups para empreendedores do mundo todo que queiram desenvolver seus negócios em Minas Gerais.

Os participantes do programa de aceleração passam por 6 meses de atividades intensas, que incluem mentorias personalizadas, eventos e difusão, trabalho no escritório compartilhado entre outras, que contribuem para fortalecer suas características empreendedoras e seus projetos. É um programa de aceleração de startups para empreendedores do mundo todo que queiram desenvolver seus negócios em Minas Gerais. É a única iniciativa deste tipo mantida com recursos públicos no país e serve para potencializar a interação, as redes e a transferência de conhecimento, juntamente com as habilidades entre empreendedores apoiados e o ecossistema local, nacional e mundial. O SEED é um típico exemplo do que proporciona uma aceleradora. Veja-se:

- Mentoria personalizada. Serviços de acompanhamento e de aconselhamento técnico, gerencial e estratégico. 
- Perks. Benefícios que as startups recebem dos nossos parceiros, com o objetivo de desonerar a aquisição de serviços básicos para o desenvolvimento de suas plataformas e aplicativos.

- Coworking. Disponibilização de escritório compartilhado e de espaço adequado para a realização de reuniões e eventos.

- Formação empreendedora. Execução de metodologia de formação empreendedora e de aceleração de negócio.

- Networking. Potencialização das interações, formação de redes e transferência.

As aceleradoras proporcionam geralmente apoio para tornar a startup "the next big thing". As aceleradoras, via de regra, desenvolvem diversas parcerias com empresas, prestadores de serviços e instituições que oferecem benefícios extras aos participantes do programa, os famosos perks. Relevante vantagem da aceleradora é que o empreendedor não precisa tirar dinheiro do bolso: o espaço ocupado não representa um custo, possibilitando a vantagem de maior rede de contatos. $O$ capital investido oferece condições de desenvolvimento, ao mesmo tempo em que a rede de relacionamentos possibilita alavancar as relações comerciais.

A participação em uma aceleração pode variar entre 5 e 20\% dos resultados, tornando-se também dona do negócio e, portanto, a pressão por resultados é bem maior. O empreendedor aprende a trabalhar sob pressão dos acionistas, que precisam conseguir lucro para trazer novos investidores. Os participantes podem conversar com mentores e especialistas de renome, das mais diversas áreas, para trocar ideias sobre seus projetos. Além disso, há específica programação, com treinamentos, eventos com empreendedores de sucesso, com a realização de pitches para clientes e potenciais investidores.

A aceleradora valoriza o espírito de colaboração e troca de experiências, por sê-lo essencial para o sucesso dos projetos. A diversidade é fundamental para a inovação, sendo importante a convivência de visões de mundo variadas, diferentes culturas e ideias. Nas incubadoras, geralmente prevalecem as seguintes características: período mais longo (até 3 anos); aceita todos os tipos de projetos de acordo com o objetivo de cada instituição; ligados a instituições como universidades; visa estabilidade e crescimento da empresa; foca na infraestrutura e desenvolvimento.

Já nas aceleradoras, prevalecem as seguintes características: período curto (em média 6 meses); priorizam projetos escaláveis; podem ser privadas ou programas do governo; busca o faturamento e lucro da empresa; foca em networking e gestão do negócio e o meio é mais competido.

Se a startup está em busca de uma inovação radical ou de um modelo de negócios escalável e repetível, merece ser procurada uma aceleradora. Mas se o modelo de negócios é baseado na economia tradicional, é provável que o ideal seja procurar uma incubadora. Esse tipo de apoio pode trazer insights significativos para o seu negócio, além de investimentos e possibilidades de expansão. Vejam-se outras distinções entre incubadoras e aceleradoras.

A incubadora, de uma forma geral, não possui fins lucrativos, sendo mantida por instituições públicas, enquanto a aceleradora é uma instituição privada, possui fins lucrativos e é mantida por investidores, que buscam obter lucro com o retorno da venda de ações da empresa sob seus cuidados. O conceito de incubadora nasceu no âmbito acadêmico e governamental. A aceleradora é 
normalmente uma entidade privada. Em contrapartida, a aceleradora oferece aporte financeiro e ajuda a captar investidores. A incubadora apenas auxilia no preparo para receber investimentos de outras entidades. A união de uma aceleradora com uma startup visa ao lucro como objetivo e existe uma cobrança muito maior de resultados. $\mathrm{Na}$ incubadora, o ritmo é menos acelerado, pois muitas vezes ela não tem fins lucrativos. A incubadora transforma ciência em negócios, já as aceleradoras procuram negócios mais estabelecidos e que estejam em um estágio um pouco mais avançado. $O$ processo de incubação busca validar as ideias e criar valor para as empresas geradas. Para se manter no espaço, normalmente a nova empresa paga um percentual do faturamento de seu último ano de incubação, algo entre 2 e 5\%. Nada impede que uma empresa, depois de passar por uma incubadora, ainda passe por uma aceleradora, onde poderá reforçar a gestão e sua rede de contatos, garantindo maior respaldo para seu futuro. As incubadoras oferecem suporte gerencial e técnico para que se desenvolvam e prosperem no mercado.

Entre os serviços oferecidos por uma incubadora estão: espaço físico; acesso à internet; telefonia; conexão com instituições financeiras, instituições de pesquisa e órgãos governamentais; e apoio administrativos e assistenciais em diferentes áreas, como marketing, finanças, contabilidade, recursos humanos e jurídica.

As aceleradoras associadas a uma startup almejam uma participação na empresa de 5 a $20 \%$. No caso das incubadoras, essa participação pode acontecer, porém, isso não é comum e a fatia é ainda menor. A incubadora oferece principalmente infraestrutura e espaço físico, enquanto que a aceleradora oferece suporte de gestão e orientações através de profissionais qualificados, ajudando a ampliar a rede de relacionamentos do novo projeto.

$\mathrm{Na}$ incubadora, a participação geralmente é gratuita, ou através do pagamento de taxas subsidiadas pelo próprio empreendedor, não havendo qualquer tipo de investimento de capital para seu desenvolvimento. Na aceleradora, o empreendedor cede parte das ações de seu projeto em troca de investimentos de capital.

O período que uma empresa permanece numa incubadora pode chegar a dois anos, recebendo apoio em atividades de marketing, assessoria de imprensa e elaboração do plano de negócios, ao fim do qual a empresa é considerada graduada. Além disso, "incubadoras" e "aceleradoras" são fortemente caracterizadas por serem instituições com grande conhecimento de mercado e gestão, o qual é usufruído pela startup por elas financiada. As "incubadoras" são caracterizadas por serem entidades destinadas ao fomento financeiro de empresas startup cujo produto ou serviço tenham particular interesse estratégico ou econômico para uma determinada região ou entidade do Poder Público. Deste modo, as "incubadoras" estão interessadas em um determinado "nicho" de mercado e buscam se aliar a empresas que ofereçam produtos ou serviços vinculados a tal "nicho". É também comum que a "incubadora" tenha seu capital direta ou indiretamente proveniente do Poder Público, o que torna a formalização da relação com a empresa startup e os controles sobre o uso dos recursos investidos mais burocrático e sujeito a regras mais rígidas.

Revista do Direito [ISSN 1982-9957]. Santa Cruz do Sul, n. 63, p. 131-162, jan. 2021. https://online.unisc.br/seer/index.php/direito/index 


\section{A RELEVÂNCIA DE UM ECOSSISTEMA VERDADEIRAMENTE EMPREENDEDOR: EM PROL DA TECNOLOGIA, DIREITO E INOVAÇÃO}

Ser um ecossistema empreendedor não é uma tarefa simples. Afinal, os resultados podem ser incríveis, não só para os fundadores, como para toda a região. Mas o processo dá trabalho. Ecossistema Empreendedor ou de Inovação é o ambiente, formado pelos mais diversos stakeholders do empreendedorismo, em que há interconexão, ausência de hierarquia, há equilíbrio e há dinamismo. O conceito não advém o termo das ciências biológicas sem motivo. Afinal, parte-se do pressuposto de que tal como ocorre entre as espécies, no empreendedorismo um também necessitase dos demais para sobreviver.

Assim, o "meio ambiente" do Ecossistema Empreendedor revela-se composto por instituições de pesquisa e ensino, empresas, empreendedores, governo, incubadoras, aceleradoras, associações de classe e prestadores de serviço. Percebe-se que no Ecossistema Empreendedor a inovação e o empreendedorismo são vistos como um processo dinâmico e conjunto, pelo qual o conhecimento é acumulado via do aprendizado e da interação entre os stakeholders. Um ecossistema de startups denominado também de ecossistema empreendedor é tido como o "ambiente" que afeta as startups.

O ecossistema é uma sociedade de empreendedores, ideias, habilidades, startups, incubadoras, mentores, capital, entre outros atores. Um ecossistema de startup, assim como um ecossistema biológico, pressupõe que seus elementos interajam de forma harmônica, buscando sempre a adaptação quando ocorre a extinção de algum componente. Consequentemente, a inexistência de um elemento causa um desequilíbrio e quase sempre afeta outro(s) elemento(s) do ecossistema. Exemplo: a falta de qualificação profissional afeta as habilidades da equipe. Isso deixa claro que a omissão de um ou mais elementos afeta também a existência de outros.

A identificação dos elementos de um ecossistema saudável permite uma gestão estratégica, visto que através dele é possível identificar os desafios e as oportunidades que o cercam. Atualmente, a principal referência sobre Ecossistema Empreendedor é o professor Daniel Isenberg, da Babson College, que possui o texto, "The Big Idea: How to Start an Entrepreneurial Revolution", no qual Isenberg faz nove recomendações para formuladores de políticas públicas e para outros atores sobre como criar um Ecossistema que favoreça a atividade empreendedora.

Em um ecossistema empreendedor as iniciativas de apoio ao empreendedorismo são tomadas, necessariamente, em rede. É um ambiente no qual há diversos atores que oferecem suporte e apoio para as startups se desenvolverem. Geralmente, o ecossistema é identificado como uma cidade ou região. Têm-se como clássico exemplo o Vale do Silício - Estados Unidos, região em que as maiores empresas de tecnologia estão inseridas, como o Facebook e Google.

Já no Brasil, duas cidades que vêm se destacando, quais sejam, Belo Horizonte/MG e Florianópolis, em Santa Catarina. As comunidades podem ter várias formas. Estar em um lugar físico ou não, funcionar com um modelo de sociedade ou não. Várias, como San Pedro Valley, em Horizonte, Minas Gerais, nasceram inspiradas no Vale do Silício, e possuem as características de onde estão inseridas. Ao se ler o livro Startup Communities: Building an Entrepreneurial Ecosystem in Your City (em português, Comunidades de Startups: Construindo um Ecossistema Empreendedor na sua Cidade), Brad Feld mostra-nos necessidades para que as comunidades obtenham sucesso. $O$ 
livro é baseado em sua experiência de mais de 20 anos como empreendedor e contribuindo com startups. Assim, após longos anos, ele observou as estratégias das comunidades que mais prosperaram e criou a conhecida Teoria Boulder. Esta teoria perpassa por quatro premissa, quais sejam:

- Para que a comunidade de startups seja duradoura, é importante promover eventos que engajem. Não valem só festas.

- Como os líderes são objetos centrais, é necessário que se comprometam. Muitas vezes, durante um longo período de tempo.

- Ecossistemas empreendedores são formados por leaders (ou líderes: os empreendedores) e feeders (ou fomentadores: todos os outros agentes, como governo). Mas os empreendedores precisam ser o centro.

- Os ecossistemas que dão certo têm uma filosofia de inclusão. É preciso que todos que quiserem possam participar e dividir suas ideias e experiências.

Nota-se pela análise do livro que a comunidade se forma quando empreendedores fazem o que sabem de melhor, ou seja, criar coisas. Os pilares que tornam uma cidade ou região um ecossistema de startups vibrante e saudável advém da interação do governo, disponibilidade de capital, cultura, suporte, talento e mercado. Ao que parece, tais ecossistemas são mais fáceis de se encontrar em grandes centros urbanos, dentre eles, São Paulo, Rio de Janeiro e Belo Horizonte.

Mas aos poucos isso está sendo alterado. Tanto é que em 2018 a Abstartups iniciou a mapear e diagnosticar as comunidades de startups brasileiras. Foi possível ver a expansão de outras cidades, tais como como Fortaleza, Campinas e Recife, as quais já estão entre as cidades com maior número de startups em todo o Brasil. Encontram-se inseridas Caxias do Sul e Campo Grande, as quais também estão trabalhando para criar o ambiente ideal para geração de novos negócios. Em Belo Horizonte, especificamente em relação ao San Pedro Valley (SPV), este foi criado por alguns amigos. Iniciou-se quando Matt Montenegro (Beved) conheceu Diego Gomes (Rock Content) na Via6. Se juntaram a Yuri Gitahy (Aceleradora), a Edmar Pereira (Rock Content), a Bernardo Porto (Hotmart) e a Vítor Peçanha (Rock Content), dando os primeiros passos do que viria a ser um dos ecossistemas de referência no país.

Nada disso seria possível se eles não juntassem suas forças. E afinal, o que é uma comunidade de startups? Pode-se dizer que é um conglomerado, normalmente localizado em uma cidade ou região, que é formado por startups em diversos estágios que interagem com todo o ecossistema em busca de mais oportunidades e desenvolvimento. Se for bem desenvolvida, uma comunidade de startups proporciona mais oportunidades, engajamento de investidores, do governo, também das grandes empresas e cria parceiros potencializando o desenvolvimento de uma região. Os benefícios são o apoio maior a novos empreendedores na região, o que resulta na troca de experiências e uma economia mais próspera.

De fato, não há um ecossistema empreendedor sem eventos. É durante os eventos que todos têm chance de se conhecerem e dividir suas ideias, atuações, experiências, desafios e perspectivas. 
Um dos primeiros eventos do San Pedro Valley (SPV), foi um famoso meetup ainda em 2009, com as primeiras empresas participantes. E, em 2016, a comunidade promoveu o San Pedro Valley Summit, com mais de 1.200 pessoas. O San Pedro Valley foi lar de algumas grandes startups nacionais como a Take.net, Sympla, Melliuz, Hotmart e Rock Content. Mais comunidades também foram ganhando destaque no Brasil, tais como o Startup Mt, Reed Foot, Startup SC, Cariocas e outras.

Vê-se que as startups sempre foram mais presentes nos grandes centros urbanos como São Paulo, Rio de Janeiro, Belo Horizonte e Florianópolis, devido a ecossistema saudável proporcionado por governo, disponibilidade de capital, cultura, suporte, talento e mercado. Repare-se, por exemplo, que em Belo Horizonte, São Paulo ou Rio de Janeiro, mostra-se mais fácil ver iniciativas de grandes corporações, tais como Oito, Oxigênio, Cubo, além de programas de desenvolvimento governamentais (Pitch Gov, Seed, Desenvolve SP, ), investidores, cultura, suporte e grandes universidades (PUC, UFMG, Estácio, FIAP),.

É certo que muitas startups aparecem todos os anos, mas muitas também desaparecem. Justamente por isso, os eventos necessitam promover algo além de só networking. Para se ter um ecossistema saudável, é necessária cultura, a qual é um dos mais importantes elementos para um ecossistema de sucesso. Há difusão de cultura empreendedora por meio de eventos que tratem de startups, concedendo visibilidade dos cases de sucesso e êxito, juntamente com os locais e meios para ensino de técnicas de empreendedorismo.

Deve-se contar com talentos (recursos humanos), pois a é essencial para a criação e permanência de um ecossistema saudável empreendedor. Envidar esforços e investir em capital humano é salutar, seja para reter e criar a força de trabalho não apenas para o campo de startups, mas para também favorecer a inovação nos negócios de agora e para ao logo do tempo futuro. São muito importantes as universidades e seus respectivos programas de empreendedorismo, que almejam promover formação, retenção e motivação de talentos. Há necessidade de se ter conexão e suporte de instituições. Isso, pois, reunir talentos e empresas é um dos fatores positivos para comunidades de sucesso e ecossistemas saudáveis, por meio de hubs físicos e locais onde as pessoas possam se encontrar e compartilhar experiências, bem como sua infraestrutura de suporte ao empreendedorismo. O mercado, em si, deve ser favorável. Ou seja, as grandes empresas que estão inseridas na comunidade revelam-se uma parte fundamental do ecossistema que se caracteriza como sendo saudável. O relacionamento destas grandes empresas perante a comunidade ocorre diversas maneiras, quais sejam, através editais, coworkings, apoio a eventos, criação de aceleradoras ou parcerias com as próprias startups. Ademais, há necessidade de se ter acesso a capital financeiro, mediante apoio financeiro e as ações da comunidade para se tornar atrativa para investimentos e "encher os olhos dos investidores". Nesse sentido, a presença de investidores anjo e fundos de investimentos incentivam e contribuem para a alavancagem de atividades e surgimento de novas iniciativas. Também é necessário que se tenha um ambiente regulatório favorável, por políticas públicas que facilitem as relações entre o governo e a comunidade, a começar pelos próprios programas disponíveis para regulamentação, financiamento, debates e discussões. 
A infraestrutura necessária para desenvolver startups exige estar em um local que oferece boa qualidade de vida e, nesse quesito, capitais menores tendem a se destacar. É importante deter bons lugares de passeio, praças arborizadas, clima ameno, ruas limpas e trânsito menos congestionado. Pode-se obter os benefícios das cidades grandes sem passar pelo caos presente nelas. Com um clima de mais tranquilidade, as pessoas se sentem mais relaxadas e criativas e tendem a criar novas ideias com mais facilidade. Também, além disso, o ambiente tranquilo possui menos stress, e isto impacta reflete positivamente na produtividade e criação de ideias. O sistema tributário de muitos países se apresenta como um fator limitante para o crescimento saudável do ecossistemas de startups. Isto ocorre porque alguns países, como o Brasil, apresentam taxas elevadas de juros, morosidade em processos e poucos incentivos ao mercado quanto as empresas falidas.

Existem relatos de que existe capital de investimento suficiente, mas poucos têm acesso. Os investidores argumentam que falta estrutura legal que os incentive a investir em empreendimentos de maior risco. Estes investidores preferem investir em grandes empresas, onde os riscos são menos elevados. De acordo com a Associação Brasileira de Startups - ABStartups, são as seguintes comunidades no Brasil.

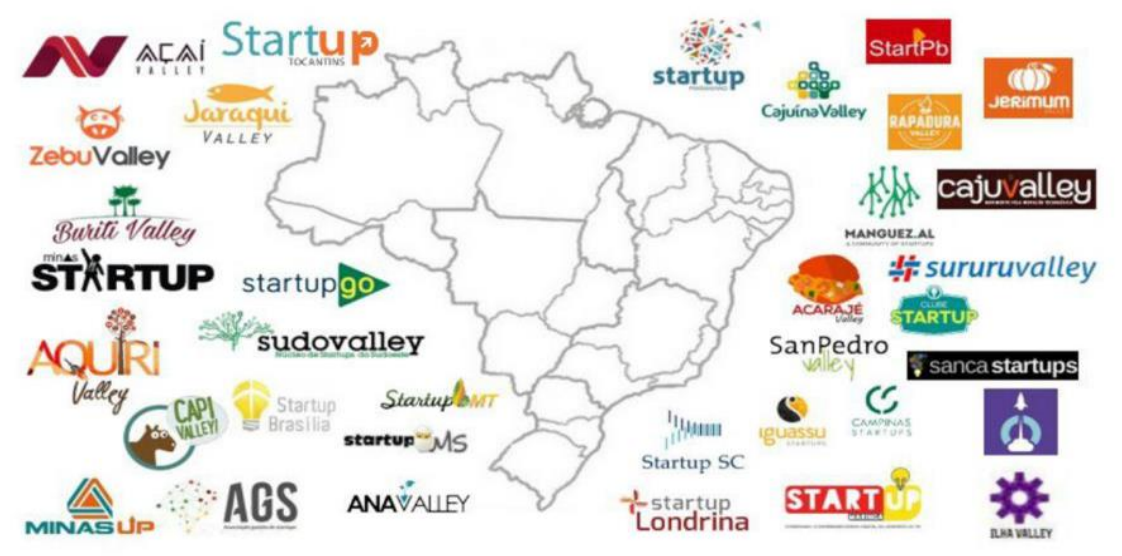

Interessante constatação em parceria com a Accenture mostra que $73 \%$ das startups estão localizadas em 10 comunidades. Passaram a compor a lista Brasília, Fortaleza, Londrina, Curitiba e Uberlândia. No mínimo, 130 estão no Brasil, valendo-se de nomes exóticos, relacionados a alguma característica da respectiva região, tais como Pequi Valley, em Goiás, a Caju Valley, em Aracaju, a Red Foot, em Londrina e a Rapadura, em Fortaleza. A pesquisa realizada pela ABStartups em parceria com a Accenture, com a participação de mais de mil startups de todos os estados do país, demonstra que Santa Catarina é o segundo estado com maior número absoluto de startups. Após, está Minas Gerais e Rio de Janeiro, atrás apenas de São Paulo. Interessante também é que o Ceará é o primeiro colocado da região Nordeste, na frente de Pernambuco, na oitava e nona posições. Curioso é também a presença do interior, via Uberlândia / MG, Joinvile / SC e Blumenau / SC, que ocupam a sexta, sétima e décima posições, respectivamente. Vejam-se as cidades com maior eficiência para criação de startups: 


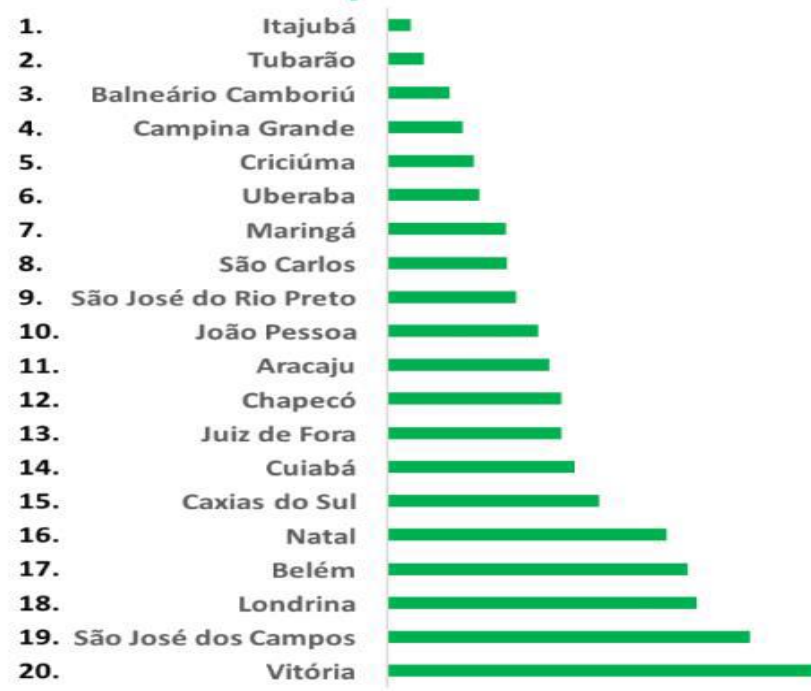

Dados da pesquisa ABStartups e Accenture (2017), cruzados com o PIB dos municipios segundo o IBGE (2014).

Vejam-se os Estados com maior número de startups no Brasil, e quais as cidades também possuem maior número de startups.

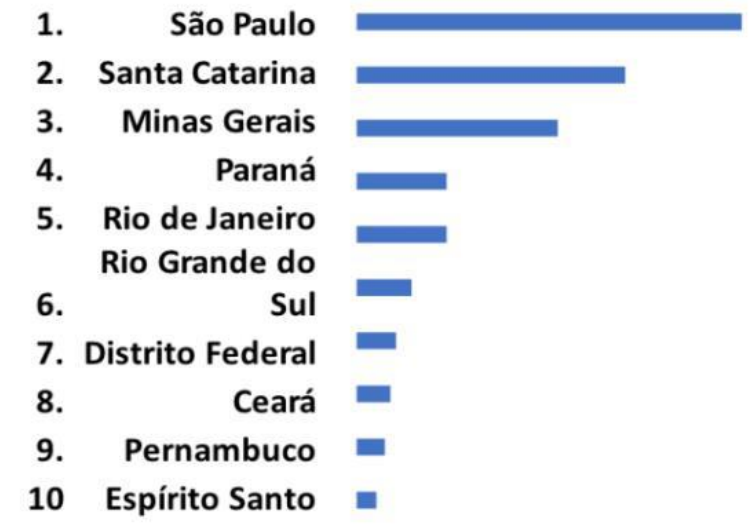

Fonte: ABStartups e Accenture (2017).

A pesquisa realizada pela $A B S t a r t u p s$ ainda aponta que o estado de Santa Catarina lidera os 3 primeiros lugares entre as cidades com mais densidade, com Florianópolis, Chapecó e Joinville. Dentre a "top 10" cidades mais densas em startups, 6 estão no estado. 

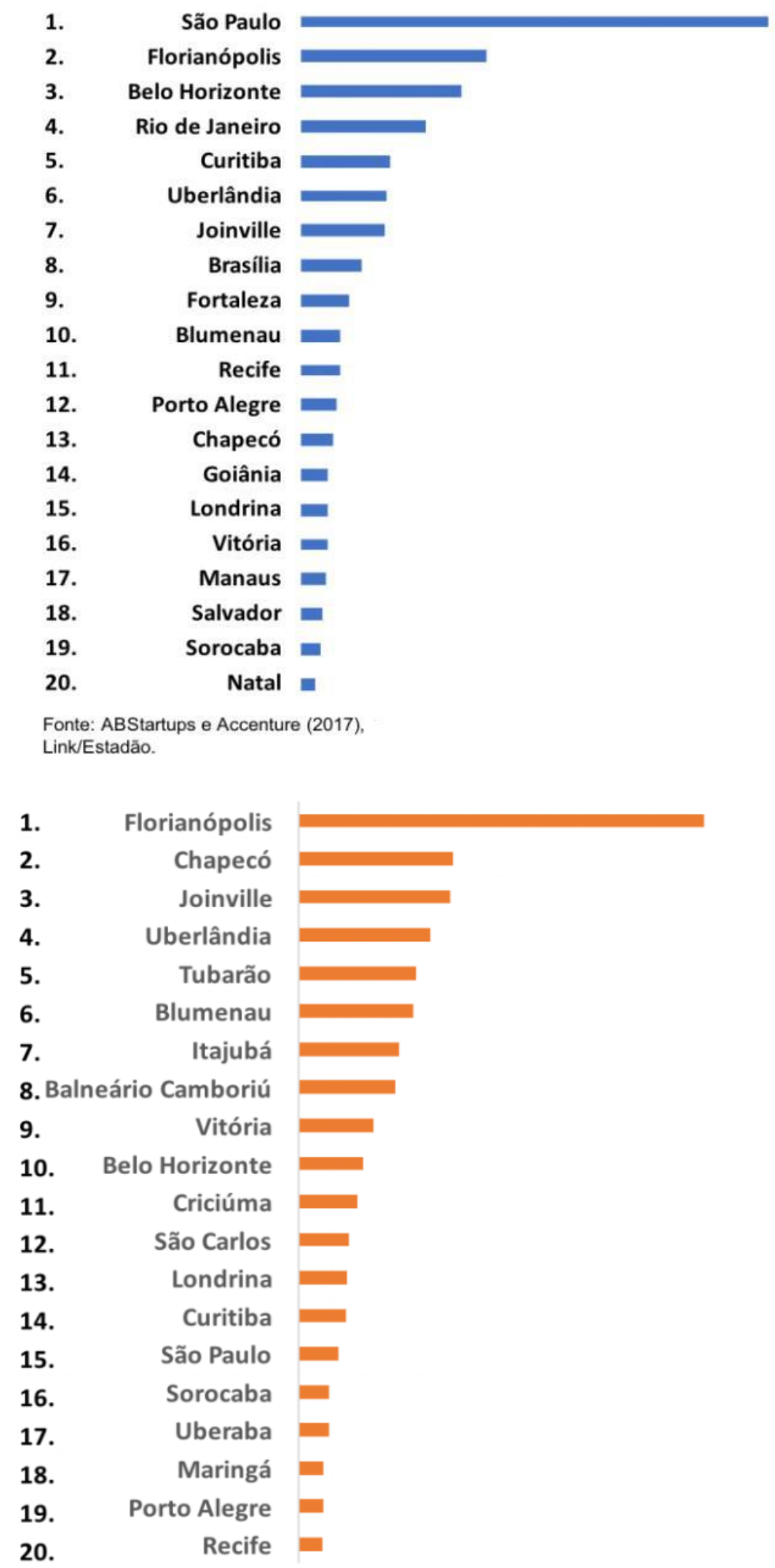

Dados da pesquisa ABStartups e Accenture (2017), cruzados com a população dos municipios segundo o IBGE (2014),

Considerando-se os diversos fatores que atuam no ecossistema Brasileiro, poderíamos exemplificar da seguinte maneira. Para se fazer Network: 


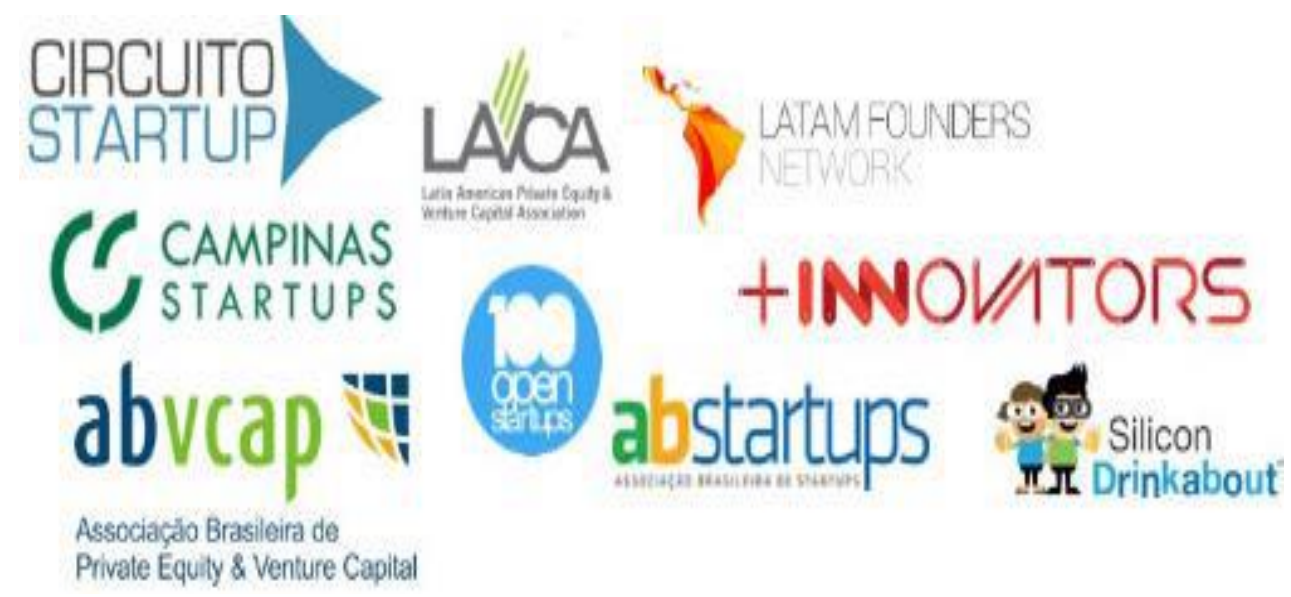

Para quem almeja coworking:

\section{wework pLUG DISTRITO E\&U:}

CAMPUS

SÃO PAULO

a Google space

\section{AHOY \\ 重 Raja Valley}

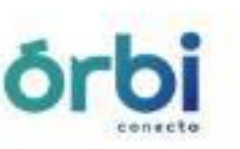

STARTUP

inovaBra

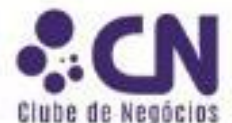

\section{.}

Clube de-Negócios
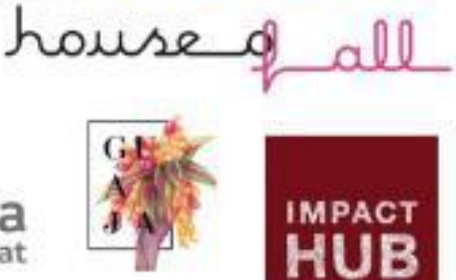

IMPACT

HUB

CO.W.n.m

Para se obter mídia, cultura e eventos, há, por exemplo em nosso ecossistema.

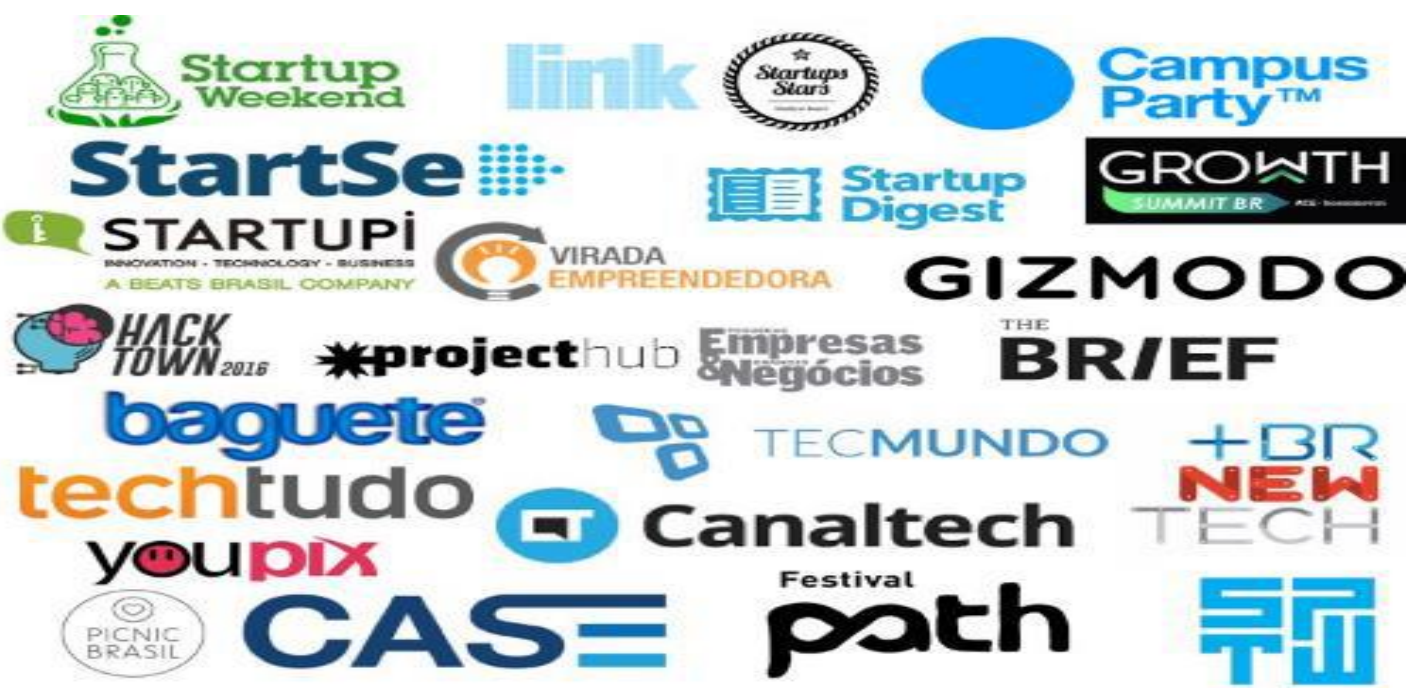


Para fins de aperfeiçoamento educacional e acadêmico, o Ecossistema Brasileiro possui alguns exemplos:

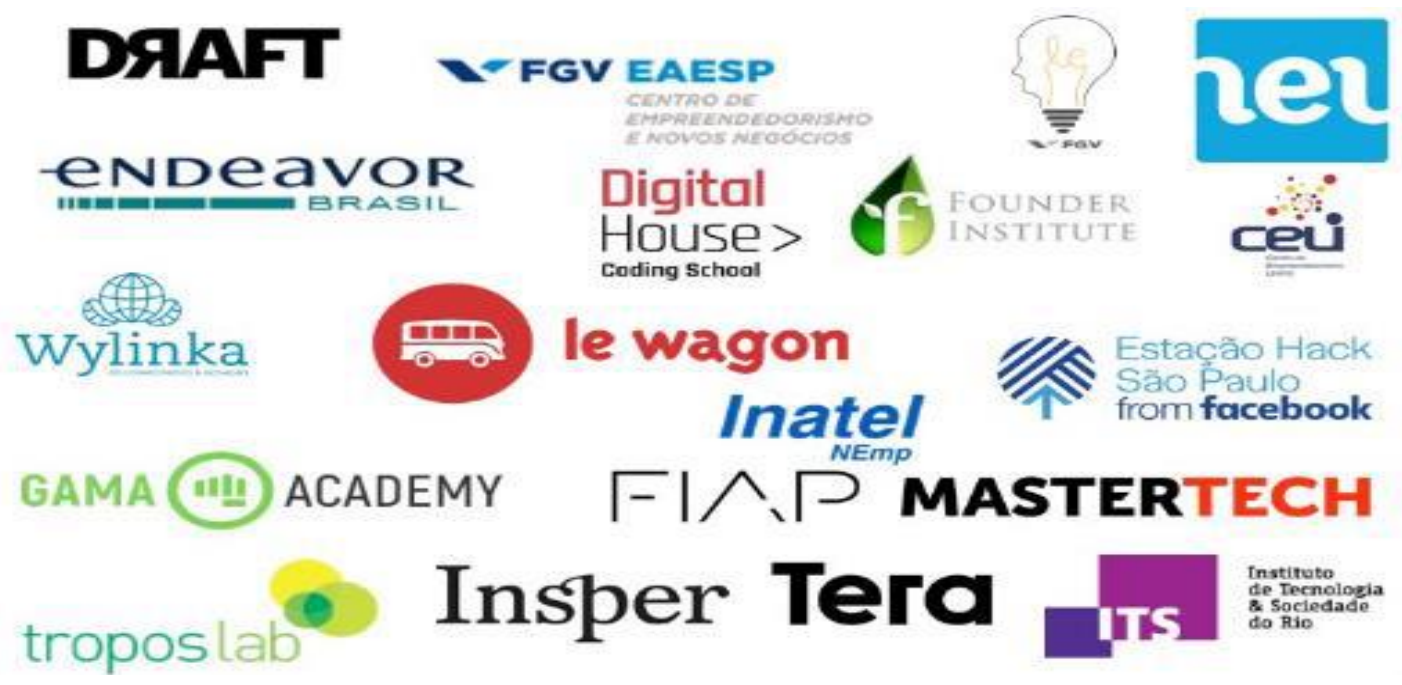

Quanto ao acesso a investimento em Venture Capital, o ecossistema no Brasil dispõe de participação nacional e estrangeira.
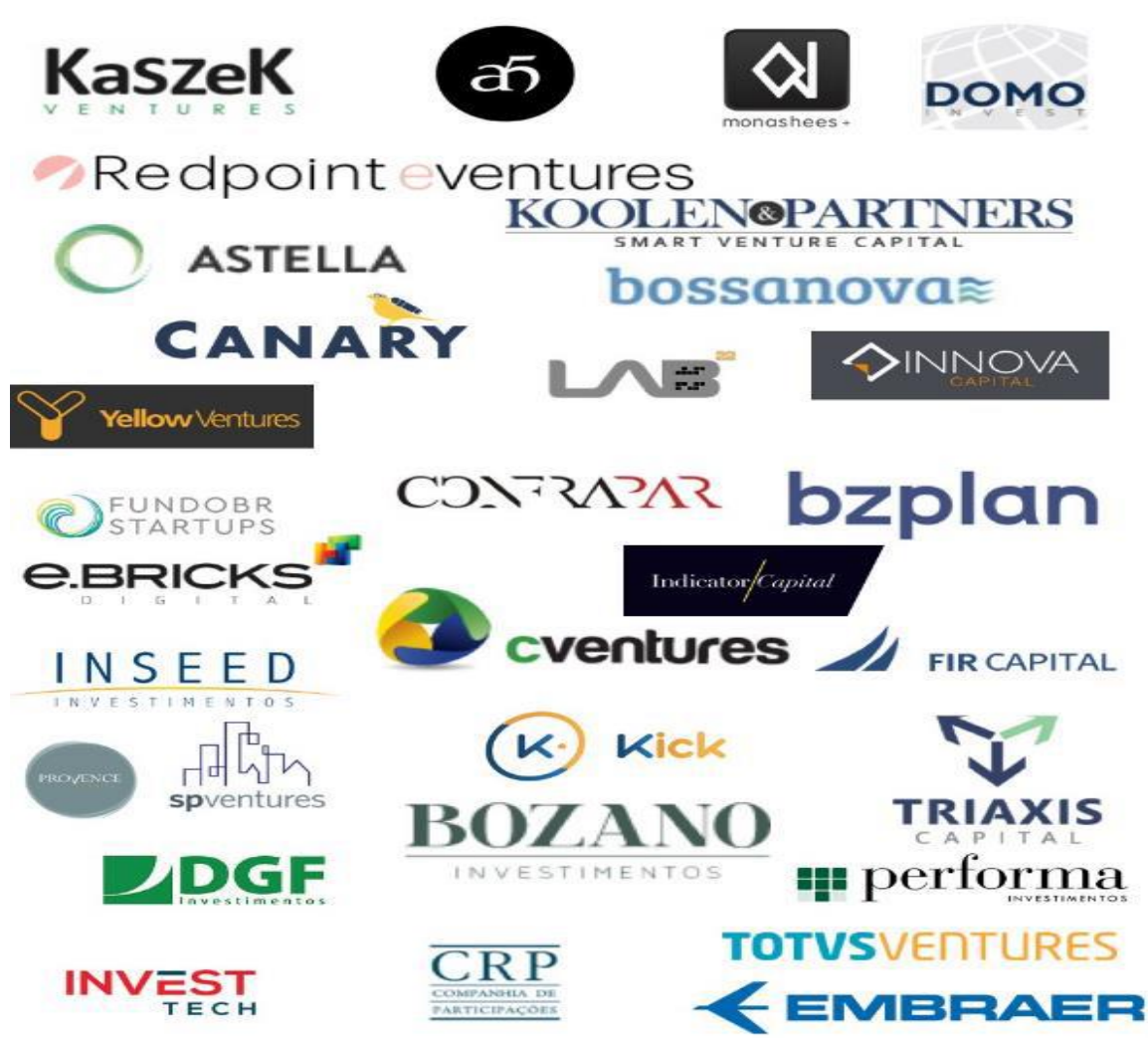


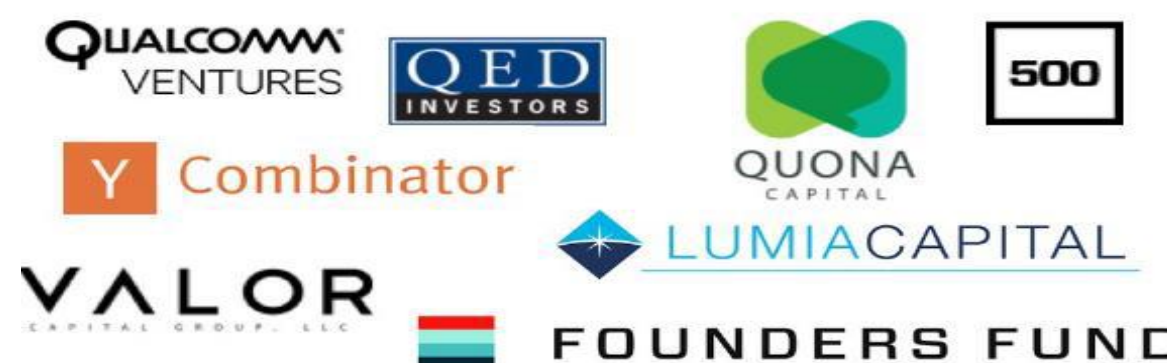
eles:

O Ecossistema de Startups no Brasil conta também com redes de Investidores Anjo, dentre

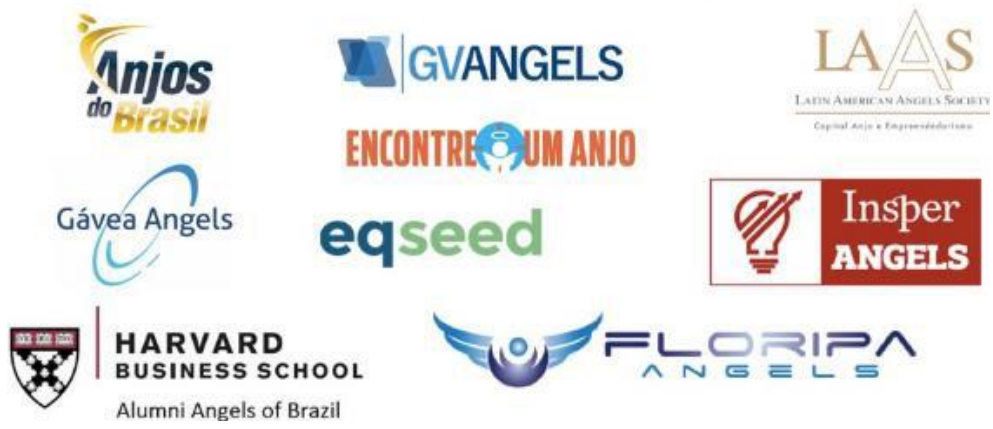

Nosso ecossistema também permite apoio junto a grandes e renomadas empresas (atividades), dentre elas, como exemplo:

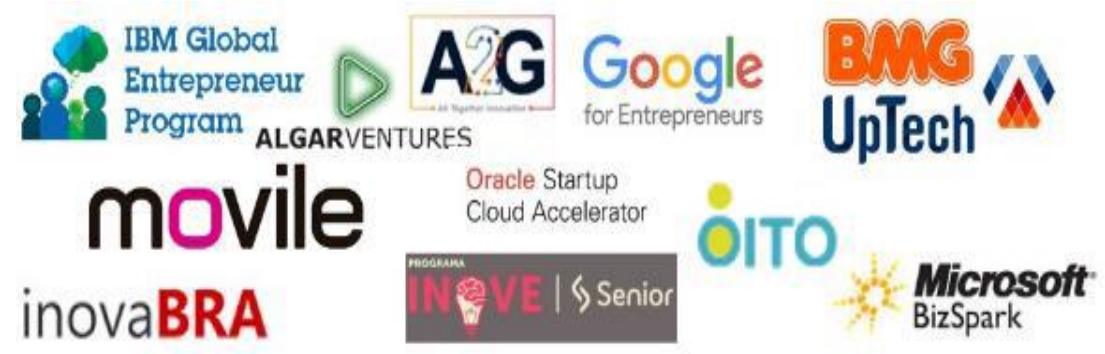

Mencione-se também que em relação a auxílio e incentivos governamentais, o Brasil dispõe, principalmente dos seguintes:

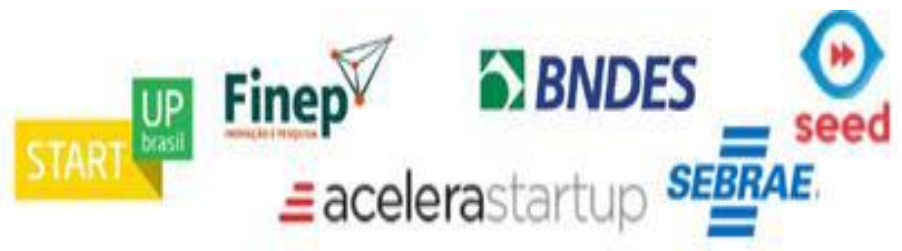
estão:

O Brasil, em seu ecossistema, conta também com renomadas aceleradoras. Dentre elas 


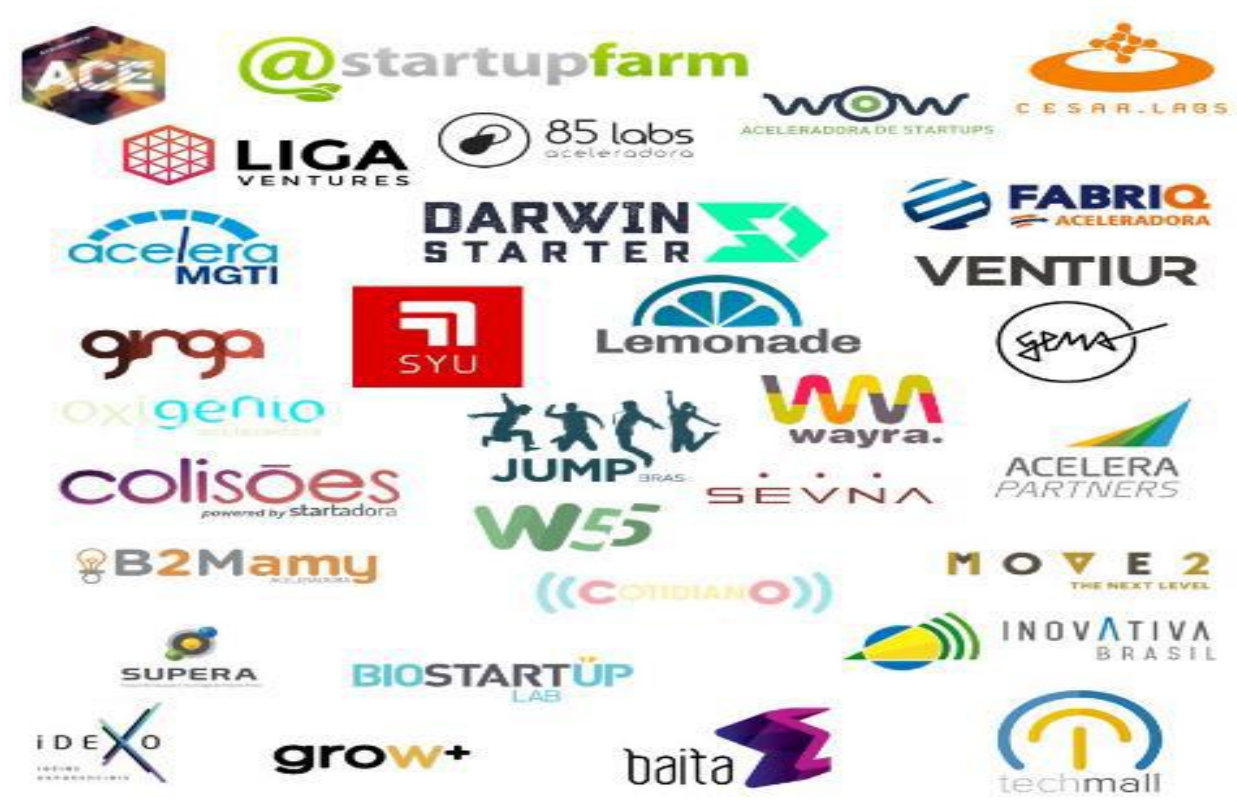

Portanto, o ecossistema de uma startup pode ser definido como o ambiente que afeta as startups, com destaque aqui para instituições que incentivam o desenvolvimento de inovação e empreendedorismo, incluindo universidades, incubadoras, venture capital (VC), etc. E, para que os ecossistemas possam ser melhor apoiados e serem cada vez mais saudáveis é interessante identificar os diversos elementos que compõem este ecossistema, bem como compreender como as startups operam, os desafios enfrentados por estas e também como superá-los ou minimizá-los.

As cidades sedes de ecossistemas de startups possuem características comuns como: educação voltada para o empreendedorismo, o que geralmente explica a presença de uma cultura empreendedora e empreendedores qualificados, mediante incentivos governamentais e melhor qualidade de vida, o que gera estímulo para empreender nas referidas cidades. Por outro lado, evidentemente, em cidades, estados e países onde as oportunidades são escassas, tendem a existem dificuldades quanto a elementos do ecossistema, dentre eles, incentivos financeiros e educação.

\section{CONSIDERAÇÕES FINAIS}

Este artigo possuiu o intuito de verificar quais seriam as características técnicas para se configurar uma startup, bem como identificar o que é, tecnicamente, um ecossistema empreendedor. A metodologia ser utilizada foi de método dedutivo, mediante abordagem explicativa e descritiva, com análise de bibliografia, nacional e estrangeira, toda ela especializada no cerne do tema. As startups são diferentes, por exemplo, das pequenas empresas recém abertas, e isso advém da expectativa que elas geram. Se mostram atividades iniciantes, detentoras de abordagem jovem e adaptadas ao modelo digital, tão importante nos dias atuais. Muito embora sejam pequenas, proporcionam propostas inovadoras de serviços a serem prestados ou produtos a serem produzidos e fabricados.

As principais características de uma startup são a inovação, a escalabilidade, a repetibilidade, a flexibilidade e a rapidez. Ou seja, conceitos muito semelhantes e próximos às novidades 
tecnológicas. As startups são a grande aposta do mercado e formam verdadeiros ecossistemas no mundo todo.

As Aceleradoras investem e oferecem serviços, bem como financiam o projeto desde o início e, ao final, transforma-se em sócia até o desenvolvimento completo, consolidação, aceitação e validação, momento em que provavelmente será vendida a ideia para outros investidores. Aceleradoras priorizam startups escaláveis, ou seja, de forma uniforme, com alta demanda. As incubadoras apresentam uma grande estrutura que possui a finalidade de criar, desenvolver, recepcionar e abrigar empresas principalmente na área da ciência e tecnologia. As incubadoras podem acompanhar a partir do planejamento até as reais atividades. Empresas já existentes podem fazer parte das incubadoras e, para tanto, basta intentar desenvolver o projeto buscando melhoria no serviço e produto. As inubadoras não buscam apenas o lucro. Geralmente, se encontram em centros de pesquisas, parques tecnológicos e universidades.

O ecossistema de uma startup pode ser definido como o ambiente que afeta as startups, com destaque para instituições que incentivam o desenvolvimento de inovação e empreendedorismo, incluindo universidades, aceleradoras, incubadoras, venture capital (VC), etc. Ecossistema Empreendedor ou de Inovação é o ambiente, formado pelos mais diversos stakeholders do empreendedorismo, em que há interconexão, ausência de hierarquia, equilíbrio e dinamismo. Assim, o "meio ambiente" do Ecossistema Empreendedor revela-se composto por instituições de pesquisa e ensino, empresas, empreendedores, governo, incubadoras, aceleradoras, associações de classe e prestadores de serviço.

\section{REFERÊNCIAS}

ABS - Associação Brasileira de Startups. Disponível em: Acesso: 8 de outubro de 2019.

ANPROTEC - ASSOCIAÇÃO NACIONAL DE ENTIDADES PROMOTORAS DE EMPREENDIMENTOS INOVADORES. Estudo, análise e proposições sobre as incubadoras de empresas no Brasil. Brasília: Anprotec; MCTI, 2012.

ALEISA, Eisa. Startup Ecosystems: Study os the ecosystems around the world; focusing on Silicon Valley. Toronto and Moscow, 2013.

ABVCAP- Associação Brasileira de Private Equity e Venture Capital. Disponível em https://www.abvcap.com.br/. Acesso em 8 de março de 2020.

ACE - Glossário: Entenda todos os termos sobre empreendedorismo (2015) - ACE | Aceleradora de startups. Disponível em: http://goace.vc/aceleraglossario/ Acesso em 8 de 8 de março de 2020.

ARRUDA, Carlos; et al. Causa da Mortalidade de Startups Brasileiras: O que fazer para aumentar as chances de sobrevivência no mercado?. Fundação Dom Cabral, 2013. 
Associação Nacional de Entidades Promotoras de Investimentos Inovadores (incubadoras). Disponível em https://anprotec.org.br/site/. Acesso: 5 de outubro de 2019.

AZEVEDO, I. S. C; TEIXEIRA, C. S. (orgs). Incubadoras: alinhamento conceitual [recurso eletrônico]. Florianópolis: Perse, 2016. 29p. Disponível em: <http://via.ufsc.br/wp-content/uploads/2017/07/ebook-incubadoras.pdf>. Acesso em 8 de março de 2020.

BEHA, Richard. A Máquina Secreta de Startups de Israel. Revista Forbes Brasil. 2016. p. 84-88.

BLANK, Steve; DORF, Bob. Startup manual do empreendedor: O guia passo a passo para construir uma grande empresa. Rio de Janeiro: Editora Alta books, 2014.

BRASIL. Secretaria de Assuntos Estratégicos da Presidência da República. Produtivismo Includente: Empreendedorismo Vanguardista. Brasília, Julho de 2015.

BRASIL, Anjos do. Disponível em: https://www.anjosdobrasil.net/artigos.html. Acesso em 25 set 2019.

BRASIL, Anjos do. Guia de Investimento Anjo e Documentos Legais. Disponível em: http://www.anjosdobrasil.net/uploads/7/9/5/6/7956863/guia_investimento_anjo_v2.pdf. Acesso em 25 set 2019.

$\begin{array}{lllll}\text { BRASIL. } & \text { Instrução } & \text { CVM } & 578 . & \text { Disponível }\end{array}$ http://www.cvm.gov.br/legislacao/instrucoes/inst578.html. Acesso em: 25 set 2019.

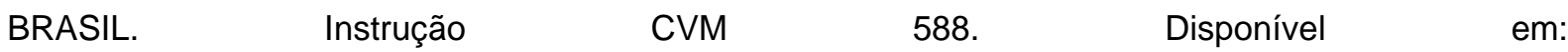
http://www.cvm.gov.br/export/sites/cvm/legislacao/instrucoes/anexos/500/inst588.pdf. Acesso em 26 set 2019.

COZZI, Afonso (Coord.). Empreendedorismo de Base Tecnológica. Spin-off: criação de novos negócios a partir de empresas constituídas, universidades e centros de pesquisa. Rio de Janeiro: Elsevier, 2008.

CROWNE, Mark. Why software product startups fail and what to do about it: Evolution of software product development in startup companies, 2000.

DOLABELA, Fernando. Pedagogia empreendedora. São Paulo: Editora de Cultura, 2003.

DORNELAS, José. Empreendedorismo na Prática: Mitos e verdades do empreendedor de sucesso. São Paulo: Elsevier, 2007. 
DORNELAS, José Carlos Assis. Empreendedorismo: transformando ideias em negócios. Rio de Janeiro: Elsevier, 2012.

EMPREENDEDOR, Serasa. O que é bootstrapping? Mantenha seu negócio sem investimentos externos! Disponível em: https://empresas.serasaexperian.com.br/blog/o-que-e-bootstrappingmantenha-seu-negocio-sem-investimentos-externos/. Acesso em 26 set 2019.

FINEP. Projeto Inovar: Glossário. Capturado em 10 jul. 2000. On line. Disponível na Internet. http://www.capitalderisco.gov.br/vcn/glossario_CR.asp. Acesso em 03 de março de 2020.

FEIGELSON, Bruno et al. Direito das startups. São Paulo: Saraiva educação, 2018. Livro digital (Epub).

FREITAS, Cristiano. Entenda 3 diferenças entre startup e empresa tradicional! Disponível em:https://syhus.com.br/2018/09/21/entenda-3-diferencas-entre-startup-e-empresa-tradicional/.

Acesso em 03 de março de 2020.

FREY, K. Políticas públicas: um debate conceitual e reflexões referentes à prática da análise de políticas públicas no Brasil. Planejamento e Políticas Públicas, n. 21, p. 211-260, 2000.

FONSECA, Adriana. Anjos profissionais: Em paralelo às suas carreiras corporativas, executivos investem em startups e oferecem mentoria aos donos de pequenas empresas inovadoras. Valor Investe. V.75. p. 59-62. Julho, 2016.

GORINI, Marco; TORRES, Haroldo da Gama. Captação de recursos para Startups e empresas de impacto. Rio de Janeiro: Alta Books, 2016.

ISMAIL, Salim; et al. Organizações Exponenciais. Por que elas são 10 vezes melhores, mais rápidas e mais baratas que a sua (e o que fazer a respeito). São Paulo: HSM Editora, 2015.

ISENBERG, Daniel.The Entrepreneurship Ecosystem Strategy asa New Paradigm for Economic Policy: Principles for Cultivating Entrepreneurship. The Babson Entrepreneurship Ecosystem Project, 2011.

JÚDICE, Lucas Pimenta (coord). Direito das Startups. Curitiba: Juruá, 2016

KALLBERG, Philip. An Analysis of Brazil's Startup Ecosystemas a Nurturing Force for InternetBasedStartups: Friend or Foe? Trabalho de Conclusão de Curso (Bachelor of Science degree)-The School of Business, University of Warwick, 2013. 
LEAL, Ana luiza; et al. Aqui vale a pena empreender. Florianópolis é a melhor cidade do Brasil para a criação de empresas, segundo um estudo inédito sobre empreendedorismo. Conheça suas vantagens e lições. Revista Exame. 2014, p.36-58.

LEGAL TALKS: Startups à luz do direito brasileiro. [recurso eletrônico] / Anna Fonseca Martins Barbosa; Eduardo Goulart Pimenta; Maurício Leopoldino da Fonseca (Orgs.) -- Porto Alegre, RS: Editora Fi, 2017.

LEMOS, Paulo A. B. As Universidades de Pesquisa e a Gestão Estratégica do EmpreendedorismoUma proposta de metodologia de análise de ecossistemas. Tese de Doutorado em Política Científica e Tecnológica. UNICAMP, 2011.

LIMA, Jaziel Pavine de. Quais são as principais fontes de investimento de capital? Disponível em: https://www.sevna.com.br/quais-sao-as-principais-fontes-de-investimento-de-capital/. Acesso em: 25 set 2019.

LUANNA SANT'ANNA RONCARATTI. Incentivos A Startups No Brasil: os casos do Startup Brasil, InovAtiva e InovApps.

MEIRA, Silvio. Novos Negócios inovadores de crescimento empreendedor no Brasil. São Paulo: Casa da Palavra, 2013.

NAGER, Mark; et al. Startup weekend: como levar uma empresa do conceito à criação em 54 horas. Rio de Janeiro: Editora Alta books, 2013.

NETO, Antônio André; ALMEIDA, Alivinio. Empreendedorismo e desenvolvimento de novos negócios. 1ª edição. Rio de Janeiro: Editora FGV, 2013.

OIOLI, Erik Frederico (Coord.). Manual de Direito Para Startups. São Paulo: Revista dos Tribunais: 2019.

OLIVEIRA, Alberto A. O. et al. O Ecossistema Empreendedor Brasileiro de Startups: Uma análise dos determinantes do empreendedorismo no Brasil a partir dos pilares da OCDE. Núcleo de Inovação e Empreendedorismo, 2013.

PARKER. Simon C. What happens to nascent entrepreneurs? Na econometric analysis of the psed. Uinversity of Durham, 2004. 
PRATA, João. Quais são as fases de investimento em uma startup no Brasil e quem são os principais agentes desse processo. Disponível em: https://projetodraft.com/quais-sao-as-fases-de-investimentoem-uma-startup-no-brasil-e-quem-sao-os-principais-agentes-desse-processo/. Acesso em 25 set 2019.

RIES, E. A startup enxuta: como os empreendedores atuais utilizam a inovação contínua para criar empresas extremamente bem-sucedidas [tradução texto editores] São Paulo: Lua de Papel,2012.

REIS, Edgar Vidigal de Andrade. Startups: análise de estruturas societárias e de investimento no Brasil. São Paulo: Almedina. 2018.

SEBRAE. 5 Principais tipos de investimento para Startups. Disponível em: http://blog.sebraees.com.br/2019/04/02/5-principais-tipos-de-investimento-para-startups/. Acesso em 26 set 2019.

SENOR, Dan; SINGER, Saul. STARTUP NATION: the story os Israel's Economic miracle. Hachette Book Group USA, 2009.

SILVA, F. Fatores que contribuem para o insucesso das Startups: O reverso da "medalha". Dissertação de Mestrado em Gestão. Escola de Economia e Gestão, Universidade do Minho, 2013.

SPINA, Felipe. Rodada de investimento: como fechar uma para sua startup. Disponível em: https://distrito.me/rodada-de-investimento-como-fechar-uma-para-sua-startup/. Acesso em 26 set 2019.

TORRES, Nágila; DE SOUZA, Cleidson. Software Startup Ecoosystems: Initial Results in the State os Pará. XI Brazilian Symposium on Information Systems, GO, 2015.

VARGAS, Daniel. O país precisa apostar no empreendedorismo. Conjuntura econômica. V.70. ำ2. P.46-47. Fev. 2016.

WOLLHEIM, Bob; NUCCIO de, Dony. Nasce um empreendedor. Dicas, provocações e reflexões para quem quer começar um negócio próprio. Portifolio/Penguin. 2016.

ZUINI, Priscila. Quem são e o que procuram os investidores-anjo do Brasil. Disponível em: https://exame.abril.com.br/pme/quem-sao-e-o-que-procuram-os-investidores-anjo-do-brasil/. Acesso em 26 set 2019. 